\title{
Future projections of the Greenland ice sheet energy balance driving the surface melt
}

\author{
B. Franco, X. Fettweis, and M. Erpicum \\ Département de Géographie, Université de Liège, Liège, Belgium \\ Correspondence to: B. Franco (bruno.franco@ulg.ac.be) \\ Received: 7 June 2012 - Published in The Cryosphere Discuss.: 4 July 2012 \\ Revised: 30 November 2012 - Accepted: 4 December 2012 - Published: 2 January 2013
}

\begin{abstract}
In this study, simulations at $25 \mathrm{~km}$ resolution are performed over the Greenland ice sheet (GrIS) throughout the 20th and 21st centuries, using the regional climate model MAR forced by four RCP scenarios from three CMIP5 global circulation models (GCMs), in order to investigate the projected changes of the surface energy balance (SEB) components driving the surface melt. Analysis of 2000-2100 melt anomalies compared to melt results over 1980-1999 reveals an exponential relationship of the GrIS surface melt rate simulated by MAR to the near-surface air temperature (TAS) anomalies, mainly due to the surface albedo positive feedback associated with the extension of bare ice areas in summer. On the GrIS margins, the future melt anomalies are preferentially driven by stronger sensible heat fluxes, induced by enhanced warm air advection over the ice sheet. Over the central dry snow zone, the surface albedo positive feedback induced by the increase in summer melt exceeds the negative feedback of heavier snowfall for TAS anomalies higher than $4{ }^{\circ} \mathrm{C}$. In addition to the incoming longwave flux increase associated with the atmosphere warming, GCMforced MAR simulations project an increase of the cloud cover decreasing the ratio of the incoming shortwave versus longwave radiation and dampening the albedo feedback. However, it should be noted that this trend in the cloud cover is contrary to that simulated by ERA-Interim-forced MAR for recent climate conditions, where the observed melt increase since the 1990s seems mainly to be a consequence of more anticyclonic atmospheric conditions. Finally, no significant change is projected in the length of the melt season, which highlights the importance of solar radiation absorbed by the ice sheet surface in the melt SEB.
\end{abstract}

\section{Introduction}

The significant increase of the surface melting (Mote, 2007; Hall et al., 2008; Tedesco et al., 2008; Fettweis et al., 2011a) and corresponding meltwater runoff of the Greenland ice sheet (GrIS) (Hanna et al., 2005; Box et al., 2006; Fettweis, 2007; Ettema et al., 2009), which accounts for more than half of its recent mass loss (van den Broeke et al., 2009), is generally attributed to Arctic warming (Box and Cohen, 2006; Hanna et al., 2008) as a consequence of an increased concentration of atmospheric greenhouse gases (GHG) (Fettweis, 2007; Stroeve et al., 2007; Hanna et al., 2008, 2009). Those parts of this surface freshwater flux that reach the bed of the ice sheet through crevasses and moulins may interact locally with the surmounting ice sheet by increasing the basal sliding of marine-terminating glaciers (Zwally et al., 2002; van de Wal et al., 2008; Sundal et al., 2011). Combined with the increasing velocity and discharge recently observed for such outlet glaciers (Rignot and Kanagaratnam, 2006; Howat et al., 2008; Rignot et al., 2008), the surface meltwater is projected to substantially accelerate GrIS mass loss under a future warmer climate (Meehl et al., 2007) and to increase sea level (Lemke et al., 2007). However, major uncertainties remain concerning these projections (Gregory et al., 2004; Cazenave, 2006).

The melt regime of the GrIS can be investigated by partitioning the energy available at the ice sheet surface to enable melt into the components of the surface energy balance (SEB), for example using data from automatic weather stations (AWS) combined with a SEB model (van den Broeke et al., 2008, 2011). The incoming shortwave irradiance (i.e. solar radiation) absorbed by the ice sheet surface is highlighted as the largest energy source for enabling the surface 
melt in Greenland, mainly depending on the surface albedo and cloud cover (van den Broeke et al., 2008). Indeed, the surface albedo is closely linked to surface melt: while the freshly fallen snow reflects most of the incoming solar radiation, the melt-induced lower albedo of the wet snow or the bare ice allows more solar energy to be absorbed by the ice sheet surface, which amplifies the melt. Because of this positive feedback loop, the surface albedo appears to be the dominant driver of surface melt variability in the ablation zone of the GrIS (van den Broeke et al., 2008; Box et al., 2012) and is believed to amplify the general warming in the Arctic (Lindsay and Zhang, 2005; Stroeve et al., 2005). Such projected changes in climatological conditions are expected to affect the surface melt of the GrIS (Meehl et al., 2007). Therefore, partitioning the projected SEB alterations during melt in response to a warmer climate over Greenland should offer an opportunity to investigate the projected GrIS melt regime and perturbations therein.

Different scenarios of global warming produced by GCMs (global circulation models) are available for investigations of this issue, but the SEB (especially the surface albedo) in the GCMs is still found to be lacking in accuracy, mainly because of inadequate parameterizations (Roesch et al., 1999; Yoshimori and Abe-Ouchi, 2012). However, regional climate models (RCMs), parameterized for polar regions and fully coupled with a physical multi-layer snow model, are particularly well designed to solve the SEB and to estimate the surface melt of the GrIS at high spatial resolution (10-25 km). Given the lack of measurement on the scale of the entire ice sheet, RCMs such as MAR (Fettweis, 2007) and RACMO2/GR (Ettema et al., 2009) are the best tools for estimating the surface mass balance (SMB) of the GrIS. Using reanalysis data as forcing fields at the lateral boundaries, they have satisfactorily simulated the GrIS melt extent on a daily time scale with respect to microwave satellites (Fettweis et al., 2011a) and the SMB along the K-transect (Franco et al., 2012), from a stake array at $67^{\circ} \mathrm{N}$ in southwest Greenland that extends from the ice sheet margin towards the central part (see van de Wal et al., 2005 and van den Broeke et al., 2008). RCMs forced by the outputs of future projections performed with GCMs could be valuable in the process of assessing the GrIS SEB changes induced by a warming of Greenland through the 21 st century. Such experiments have also demonstrated their importance for gauging the future GrIS contribution to the global sea level rise (SLR), as in Fettweis et al. (2011b).

In this study, the MAR model is run over Greenland throughout the 20th and 21st centuries at a spatial resolution of $25 \mathrm{~km}$, according to different GHG concentrations and forced by outputs produced by GCMs from the World Climate Research Programme's (WCRP's) Coupled Model Intercomparison Project phase 5 (CMIP5) multi-model dataset that was prepared for the Fifth Assessment Report of the Intergovernmental Panel on Climate Change (IPCC AR5). The MAR results are used to evaluate the GrIS surface melt anomalies and the changes of the different SEB components (i.e. the absorbed solar radiation, the longwave emission from the ice sheet surface, and the turbulent fluxes of sensible and latent heat) related to future near-surface air temperature (TAS) increases, compared to the present-day climate (gauged here over 1980-1999). Such an analysis makes it possible to highlight the different responses of the SEB components to significant Greenland warming. Furthermore, as the GrIS SEB is here calculated during melt events only, this work aims to investigate the inter-annual and spatial contribution of each SEB component to the anomalies of the net energy flux available at the ice sheet surface to enable the melt. Analysis of the projected precipitation, runoff of meltwater and SMB of the GrIS will be part of a further study; refer to Fettweis et al. (2012a) on this issue.

The MAR model and the simulations performed in this study are developed in Sect. 2 and then evaluated in Sect. 3 for the present-day climate (1980-1999). Section 4 is devoted to the evaluation of the GrIS melt anomalies throughout the 21st century. The following Sect. 5 and 6 analyse the annual anomalies of the SEB components related to TAS changes (compared to the present-day climate) and their spatial distribution over the GrIS, respectively. Section 7 focuses on the surface albedo anomalies. In Sect. 8 the annual SEB changes are also assessed over the bare ice area. Finally, this study concludes with a short discussion of the results.

\section{Data and method}

\subsection{The MAR model}

The GrIS outputs used in this study were produced by the regional climate model MAR (Modèle Atmosphérique Régional), fully coupled with the energy balance-based snow model SISVAT (Soil Ice Snow Vegetation Atmosphere Transfer) resolving the interactions between the atmosphere, the sea ice, the snow-covered tundra and the ice sheet surface. Refer to Gallée and Schayes (1994) and Fettweis (2007) for a detailed description of this model. The MAR version used for this work was the same as Fettweis et al. (2011a) with two exceptions: this study used a new tundra/ice sheet mask based on the Greenland land surface classification mask from Jason Box (http://bprc.osu.edu/wiki/Jason_ Box_Datasets), and the smoothing process of the Bamber et al. (2001) based topography for ensuring numerical stability was reduced by a factor of two. Finally, the SISVAT scheme is explained in De Ridder and Gallée (1998), Gallée et al. (2001) and Lefebre et al. (2003).

The SISVAT snow-ice model (also used in cases of deposition of snow on the tundra and the sea ice) is based on the CEN (Centre d'Etudes de la Neige) snow model CROCUS (Brun et al., 1992), in which the snow metamorphism parameterizations describe the snowpack according to its gradient of temperature, its age, its density, and the shape and size of the snow grains. The snowpack vertical discretization allows 
for the accumulation of snow on a maximum of 20 snow layers. CROCUS snow metamorphism laws control the variable thickness and the evolution of the snowpack during the simulation. A fresh snow layer is added to the snowpack when enough snow ( $1 \mathrm{~mm}$ of snowfall) is available. Both the runoff of excessive internal and accumulated surface meltwater and the drainage of excessive meltwater inside the snowpack are derived from Zuo and Oerlemans (1996). MAR assumes the formation of bare ice at the surface (with a density higher than $900 \mathrm{~kg} \mathrm{~m}^{-3}$ and an albedo near 0.45 ) if the high density melting snow (as flush) refreezes in winter for forming ice lenses or if the $10 \mathrm{~m}$ of snow prescribed at the beginning of the simulation have melted. Indeed, the CROCUS model resolves the first $10 \mathrm{~m}$ of the snowpack. If snow melt occurs and if the snowpack height is lower than $8 \mathrm{~m}$ in the snow model, an ice layer of $1 \mathrm{~m}$ is added at the bottom of the snow model. A similar rule is used in the RACMO2 model (Ettema et al., 2010).

The surface albedo is calculated according to the CROCUS snow metamorphism laws (Brun et al., 1992), as a function of the depth of the snowpack upon the ice or the tundra, the snow grain shape and size, the accumulated surface water height, the presence of bare ice or superimposed ice, the cloudiness and the zenithal solar angle. Refer to Lefebre et al. (2003) for a detailed description of the albedo parameterization in the SISVAT model.

The surface albedo, incoming solar flux, melt extent and near-surface air temperature from the MAR model have been successfully compared to satellite-derived observations over Greenland and to measurements from the Greenland Climate Network (GC-Net) (Steffen and Box, 2001) AWS (Fettweis et al., 2005, 2011a; Tedesco et al., 2011; Box et al., 2012). MAR has been used to simulate the GrIS SMB since 1958 at a resolution of $25 \mathrm{~km}$ (Fettweis, 2007; Fettweis et al., 2011a) and since 1990 at a resolution of $15 \mathrm{~km}$ (Franco et al., 2012), producing very good estimations of the SMB with respect to the K-transect measurements (van de Wal et al., 2005). Moreover, long-term MAR simulations of the GrIS SMB have already been performed for the 20th and 21st centuries (Fettweis et al., 2011b).

\subsection{Simulations}

In this study, the reference run was performed by the MAR model running at a resolution of $25 \mathrm{~km}$, forced at the lateral boundaries (with temperature, wind components and specific humidity) every $6 \mathrm{~h}$ by the ERA-Interim reanalysis from the European Centre for Medium-Range Weather Forecasts (ECMWF) for present-day climate covering 19792011. During the simulations, the daily sea surface temperature (SST) and sea-ice cover (SIC) were provided to SISVAT by the ECMWF reanalysis.

Using the same setup, the MAR model was also run over Greenland for the current climate, forced by the ERA40 reanalysis and by three GCMs (CanESM2, NorESM1-
$M$ and MIROC5) from the WCRP's CMIP5 multi-model dataset prepared for the IPCC AR5, according to the outputs from the Historical experiment (data available at http:// cmip-pcmdi.llnl.gov/cmip5/). MAR future projections of the GrIS were also performed by using the 6 hourly CanESM2, NorESM1-M and MIROC5 outputs (as well as the daily SST and SIC) from different CMIP5 representative concentration pathway (RCP) experiments as forcing fields. Refer to Moss et al. (2010) for more details about the CMIP5 RCP experiments. The different MAR simulations over Greenland carried out in the framework of this study and the periods covered by these simulations are listed in Table 1 .

These three CMIP5 GCMs have been chosen for their ability to simulate the current climate over Greenland with respect to the ERA-Interim reanalysis over 1980-1999 (Fettweis et al., 2012a). Using an automatic circulation classification type, the present-day (1961-1990) atmospheric circulation simulated by CanESM2, NorESM1-M and MIROC5 was successfully compared with reanalysis datasets (especially during summer) over Greenland on a daily time scale (Belleflamme et al., 2012). Overland et al. (2011) classified these three models among the GCMs recommended to force RCMs at a high temporal resolution over Greenland. Furthermore, MAR has already been forced satisfactorily by CanESM2 to perform current and future GrIS SMB simulations (Fettweis et al., 2011b). As highlighted by Walsh et al. (2008), assessing the ability of the GCMs for the current climate is essential before making future projections.

\subsection{Surface energy budget}

The net energy flux (NET) of the GrIS, representing the energy available at the surface of the ice sheet for enabling melt, may be partitioned in the different physical processes (the SEB components):

$\mathrm{NET}=\mathrm{LW}_{\text {net }}+\mathrm{SW}_{\text {net }}+\mathrm{SHF}+\mathrm{LHF}+\mathrm{G}_{\mathrm{s}}\left(\mathrm{Wm}^{-2}\right)$

where $\mathrm{LW}_{\text {net }}$ and $\mathrm{SW}_{\text {net }}$ are the net longwave and shortwave radiation fluxes, SHF and LHF the sensible and latent heat fluxes, and $\mathrm{G}_{\mathrm{s}}$ the subsurface conductive heat flux. $\mathrm{LW}_{\text {net }}$ represents the longwave irradiance, calculated by the difference between the longwave downward (LWD) and longwave upward (LWU) radiations. $\mathrm{SW}_{\text {net }}$ is the shortwave downward (i.e. solar energy) radiation flux (SWD) absorbed at the surface, depending on the surface albedo (ALB):

$\mathrm{SW}_{\text {net }}=\mathrm{SWD} \times(1-\mathrm{ALB})\left(\mathrm{Wm}^{-2}\right)$.

In this study, two other net shortwave radiation fluxes are also estimated by keeping either ALB or SWD constant throughout the investigated period, producing $\mathrm{SW}_{\mathrm{swd}}$ (net shortwave flux with varying SWD and constant ALB) and $\mathrm{SW}_{\mathrm{alb}}$ (net shortwave flux with varying ALB and constant SWD), respectively. When oriented towards the surface, these fluxes are defined as positive and constitute an energy 
Table 1. Forcing fields used to perform MAR simulations, scenario, covered period, and abbreviation of the simulations.

\begin{tabular}{llll}
\hline Forcing fields & Scenario & Covered period & Abbreviation \\
\hline ERA-Interim & - & $1979-2011$ & MAR-ERA $_{\text {Int }}$ \\
ERA-40 & - & $1979-1999$ & MAR-ERA $_{40}$ \\
\hline CanESM2 & Historical experiment & $1979-2005$ & MAR-CAN $_{\text {histo }}$ \\
CanESM2 & RCP 4.5 & $2006-2100$ & MAR-CAN $_{45}$ \\
CanESM2 & RCP 8.5 & $2006-2100$ & MAR-CAN $_{85}$ \\
\hline NorESM1 & Historical experiment & $1979-2005$ & MAR-NOR $_{\text {histo }}$ \\
NorESM1 & RCP 2.6 & $2006-2100$ & MAR-NOR $_{26}$ \\
NorESM1 & RCP 4.5 & $2006-2100$ & MAR-NOR $_{45}$ \\
NorESM1 & RCP 6.0 & $2006-2100$ & MAR-NOR $_{60}$ \\
NorESM1 & RCP 8.5 & $2006-2100$ & MAR-NOR $_{85}$ \\
\hline MIROC5 & Historical experiment & $1979-2005$ & MAR-MIR $_{\text {histo }}$ \\
MIROC5 & RCP 4.5 & $2006-2100$ & MAR-MIR $_{45}$ \\
MIROC5 & RCP 8.5 & $2006-2100$ & MAR-MIR $_{85}$ \\
\hline
\end{tabular}

source for melt. Therefore melt occurs if NET is positive. Finally, as $\mathrm{G}_{\mathrm{s}}$ is simulated by MAR close to zero in the subsurface ice sheet during melt, this SEB term will not be investigated here.

\subsection{Mask of daily melt events}

In the framework of this study, those SEB components are taken into account during ice sheet melt events only. Therefore, a mask of daily melt events (referred to below as $\mathrm{MSK}_{\text {melt }}$ ) is defined as the area where the daily average over the investigated period of the melt rates produced by MAR simulations is greater than $1 \mathrm{~mm} \mathrm{WE} \mathrm{day}{ }^{-1}$. Using this mask, the SEB components of the GrIS can be annually averaged with respect to the mean occurrence of daily melt events in each grid point. For example, MSK $_{\text {melt }}$ calculated for the MAR-ERA Int simulation over the 1980-1999 period resolves $93.63 \%$ of the total annual melt from the GrIS (see Table 2). However, according to the forcing fields used to perform the MAR simulations, the related masks of daily melt events differ slightly, especially towards the centre of the ice sheet. The parts of the GrIS area covered by the maximum extent (occurring mid-July) of $\mathrm{MSK}_{\text {melt }}$ for the different forcing fields over 1980-1999 and 2080-2099, as well as the part of the total GrIS melt from each MAR simulation resolved by the 1980-1999 specific mask, are summarized in Table 2.

However, it should be mentioned that such a mask based on average melt values includes pixels where melt does not occur every year, as in 1983 and 1992. Nevertheless, if the mask includes only the pixels where melt higher than $1 \mathrm{~mm}$ WE occurs each year throughout the reference period, it only resolves $46.64 \%$ of the GrIS melt for the MARERA $_{\text {Int }}$ run, compared to $93.63 \%$ with MSK $_{\text {melt }}$. In addition, melt can occur only a part of the day and then the surface temperature can be negative during the night. Selecting the pixels on the basis of a daily averaged surface temperature near $0{ }^{\circ} \mathrm{C}$ will miss such short-lived melt events.

A daily melt threshold of $1 \mathrm{~mm} \mathrm{WE}^{-1 a y^{-1}}$ appears to be an adequate compromise to highlight both the short-lived melt events in the higher ice sheet and the surface albedo positive feedback associated with the extension of the bare ice area during summer. Using a lower daily melt threshold (e.g. $0.1 \mathrm{~mm} \mathrm{WE} \mathrm{day}^{-1}$ ) involves additional pixels from highelevation areas, for which only non-significant melt events occur and which are hence almost unaffected by a decrease of the surface albedo. These additional pixels greatly contribute to dampening the surface albedo positive feedback. Conversely, a melt threshold higher than $1 \mathrm{~mm} \mathrm{WE} \mathrm{day}^{-1}$ results in many short-lived melt events being missed and tends to restrict the investigated area to the lower part of the ice sheet. While the percentage of the annually cumulated daily melt extent resolved is decreasing very quickly with an increasing melt threshold (see Fig. S1a), it still resolves the largest part of the total meltwater production of the GrIS (Fig. S1b).

In this study, all the annual anomalies of SEB components and other investigated variables provided by a MAR simulation (present or future) refer to the 1980-1999 average over the 1980-1999 MSK $_{\text {melt }}$ mask of the MAR simulation performed with the same forcing fields. This implies that $\mathrm{MSK}_{\text {melt }}$ is kept fixed throughout a simulated period, even for the future projections, while in reality the melt area varies annually and gradually spreads to higher elevations further inland on the GrIS.

An annually varying mask based on daily melt events not averaged over a multi-annual period is more representative of the melt for a given year of simulation, but does not allow intercomparison of the summers. Nevertheless, using such a varying mask does not change our analysis developed in Sect. 5 . 
Table 2. Part (in \%) of the GrIS area covered by the maximum extent of MSK $_{\text {melt }}$ and MSK $_{\text {ice }}$, and percentage of the total GrIS melt resolved by the 1980-1999 mask ( $\mathrm{PCT}_{\text {melt }}$ and $\mathrm{PCT}_{\text {ice }}$, respectively), according to the forcing fields of the MAR model. MSK melt and MSK ice $_{\text {have }}$ been implemented over the 1980-1999 period for the present-day simulations, and over the 2080-2099 period for the future projections. $\mathrm{PCT}_{\text {melt }}$ and $\mathrm{PCT}_{\text {ice }}$ have been calculated on the basis of the 1980-1999 $\mathrm{MSK}_{\text {melt }}$ and $\mathrm{MSK}_{\mathrm{ice}}$, respectively.

\begin{tabular}{|c|c|c|c|c|c|}
\hline \multicolumn{6}{|c|}{ GrIS area covered by a mask (\%) and part of the GrIS melt resolved (\%) } \\
\hline & MAR-ERA $_{\text {Int }}$ & MAR-ERA $_{40}$ & & Greenland & Ice sheet \\
\hline $\mathrm{MSK}_{\text {melt }}(\%)$ & 59.74 & 61.30 & & $2.30 \times 10^{6} \mathrm{~km}^{2}$ & $1.80 \times 10^{6} \mathrm{~km}^{2}$ \\
\hline $\operatorname{MSK}_{\text {ice }}(\%)$ & 4.96 & 4.01 & & & \\
\hline $\mathrm{PCT}_{\text {melt }}(\%)$ & 93.63 & 93.27 & & & \\
\hline \multirow[t]{2}{*}{$\mathrm{PCT}_{\text {ice }}(\%)$} & 12.74 & 10.12 & & & \\
\hline & MAR-CAN histo & - & MAR-CAN $_{45}$ & - & MAR-CAN $_{85}$ \\
\hline $\mathrm{MSK}_{\text {melt }}(\%)$ & 59.08 & - & 90.59 & - & 100.00 \\
\hline $\operatorname{MSK}_{\text {ice }}(\%)$ & 4.84 & - & 16.48 & - & 30.90 \\
\hline $\mathrm{PCT}_{\text {melt }}(\%)$ & 93.19 & - & 84.66 & - & 74.69 \\
\hline \multirow[t]{2}{*}{$\mathrm{PCT}_{\text {ice }}(\%)$} & 19.15 & - & 10.55 & - & 7.13 \\
\hline & MAR-NOR ${ }_{\text {histo }}$ & MAR-NOR 26 & MAR-NOR 45 & MAR-NOR 60 & MAR-NOR $_{85}$ \\
\hline $\operatorname{MSK}_{\text {melt }}(\%)$ & 56.51 & 73.94 & 77.67 & 82.74 & 98.94 \\
\hline $\mathrm{MSK}_{\text {ice }}(\%)$ & 3.29 & 8.02 & 8.18 & 10.52 & 16.09 \\
\hline $\mathrm{PCT}_{\text {melt }}(\%)$ & 92.74 & 88.48 & 87.11 & 85.65 & 78.95 \\
\hline \multirow[t]{2}{*}{$\mathrm{PCT}_{\text {ice }}(\%)$} & 9.74 & 6.95 & 6.26 & 5.59 & 4.34 \\
\hline & MAR-MIR $_{\text {histo }}$ & - & MAR-MIR $_{45}$ & - & MAR-MIR 85 \\
\hline $\operatorname{MSK}_{\text {melt }}(\%)$ & 63.67 & - & 85.35 & - & 100.00 \\
\hline $\mathrm{MSK}_{\text {ice }}(\%)$ & 4.98 & - & 11.76 & - & 25.05 \\
\hline $\mathrm{PCT}_{\text {melt }}(\%)$ & 93.74 & - & 87.59 & - & 78.68 \\
\hline $\mathrm{PCT}_{\text {ice }}(\%)$ & 14.02 & - & 9.06 & - & 5.99 \\
\hline
\end{tabular}

In order to investigate the SEB component anomalies on the GrIS areas covered by bare ice, another daily mask was implemented (defined here as MSK $_{\text {ice }}$ ) for each MAR simulation, based on a daily melt rate higher than $1 \mathrm{~mm} \mathrm{WE} \mathrm{day}{ }^{-1}$ and a daily surface snow density higher than $850 \mathrm{~kg} \mathrm{~m}^{-3}$ averaged over the 1980-1999 period. This new daily mask MSK $_{\text {ice }}$ is confined to the daily mean bare ice extent in the ablation zone of the ice sheet and covers smaller areas than $\mathrm{MSK}_{\text {melt }}$ (see Table 2 for the parts of the total GrIS melt resolved by the different $\mathrm{MSK}_{\text {ice }}$ ).

\section{Evaluation of the MAR simulations}

In this section, the MAR-ERA $\mathrm{Int}_{\text {Int }}$ outputs are firstly compared over a 7-yr period (September 2003-August 2010) with observations from three AWS located along the K-transect (West Greenland, a stake array along the $67^{\circ} \mathrm{N}$ latitude circle), available in van den Broeke et al. (2011). The MAR pixel closest to each AWS was selected to perform this comparison (Fig. 1). The AWS S5 is located at the ice sheet edge, S6 in the ablation zone and S9 in the accumulation zone. Refer to van de Wal et al. (2005) and van den Broeke et al. $(2008,2011)$ for further details about the K-transect and the AWS.
This figure shows that the MAR model forced by ERAInterim is able to simulate the seasonal cycle of the SEB components with respect to the AWS in the ablation and accumulation zones, and that the partitioning of the energy balance during melt conditions matches quite well the observations. The related monthly anomalies are generally less than one standard deviation over the investigated period. However, positive anomalies in the absorbed solar irradiance $\left(\mathrm{SW}_{\text {net }}\right)$ compared to the AWS data can be observed during summer (June-July-August), especially for the lower sites (S5 and S6). This is due to the fact that the bare ice albedo in the MAR model is 0.45 while it can reach values of 0.31 (Knap and Oerlemans, 1996; Box et al., 2012) in the field when bare ice appears, resulting in an overestimation of the modelled $\mathrm{SW}_{\text {net. }}$. Furthermore, as already mentioned in Fettweis et al. (2011a), MAR tends to slightly underestimate the downward longwave irradiance, inducing underestimated $\mathrm{LW}_{\text {net }}$ and air temperature throughout the year. Nonetheless, some of these $\mathrm{LW}_{\text {net }}$ anomalies are less than one standard deviation over the 7-yr period. The largest anomalies between MAR results and observations occur at S5, at the edge of the ice sheet. Since this station is located on Russell Glacier (an ice sheet promontory), the $25 \mathrm{~km}$ resolution of the MAR model is not enough to reproduce it with accuracy, resulting in an 


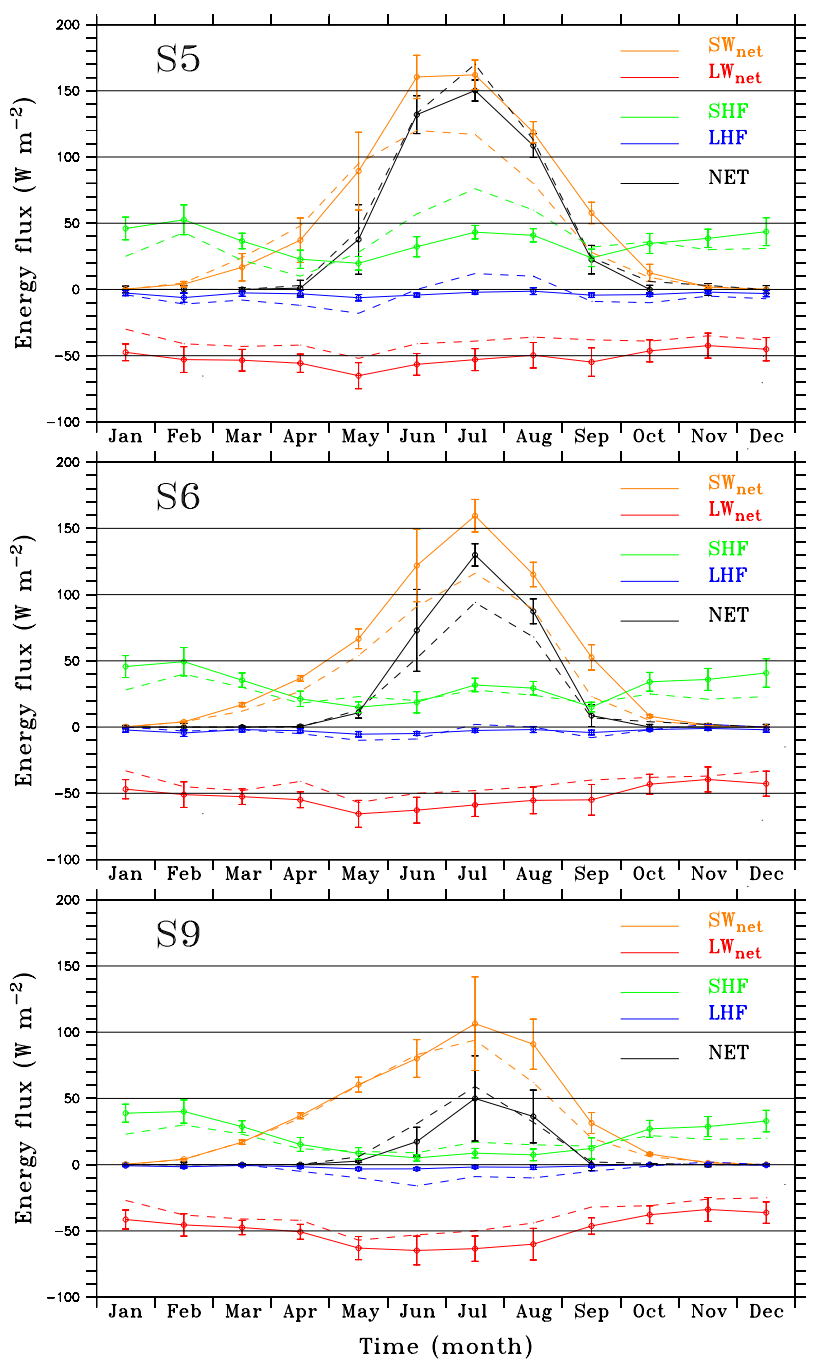

Fig. 1. Average seasonal cycle of SEB components $\left(\mathrm{W} \mathrm{m}^{-2}\right)$ simulated by the MAR model forced by the ERA-Interim reanalysis (in solid lines) over a 7-yr period (September 2003-August 2010) along the K-transect at sites S5, S6 and S9, with standard deviation over this period indicated by the error bars. Observations from the AWS available in van den Broeke et al. (2011) are drawn in dashed lines.

underestimation of the modelled turbulent heat fluxes during summer.

The surface albedo, incoming solar flux, melt extent and near-surface air temperature from the MAR model have been successfully compared with satellite-derived observations over Greenland and to measurements from the GC-Net AWS (Fettweis et al., 2005, 2011a; Tedesco et al., 2011; Box et al., 2012). For example, Box et al. (2012) used GC-Net AWS observations to evaluate the accuracy of the surface downward solar irradiance provided by ERA-Interim-forced MAR over 2000-2010, revealing average monthly biases less than the specified GC-Net sensor error $\left(15 \mathrm{~W} \mathrm{~m}^{-2}\right)$.
By comparing RCMs with spaceborne SMMR-SSM/I microwave data on a daily time scale, Fettweis et al. (2011a) and Rae et al. (2012) have highlighted that a reliable modelling of the melt extent and intensity over the GrIS is highly dependent on the ability of the RCMs to partition the energy balance at the surface of the ice sheet. For example, biases in the ratio SWD vs. LWD affect the occurrence of the melt extent maximum. Consequently, it can be assumed that an RCM able to reproduce the melt extent and intensity of the GrIS is primarily able to partition the SEB with reliability. That is why we have chosen in this study to evaluate the different present-day MAR simulations performed with ERA-40 reanalysis and GCMs as forcing fields, by comparing directly their melt outputs with MAR-ERA ${ }_{\text {Int }}$ (presented in Fig. 2) over 1980-1999. Melt anomalies with respect to the reference MAR run in such a comparison should reflect anomalies in the partitioning of the SEB.

The annual melt amounts from the GrIS simulated by the different MAR runs, as well as the melt energy flux (NET) and the different SEB components averaged over the 1980$1999 \mathrm{MSK}_{\text {melt }}$, are summarized in Table 3. It appears that the MAR model forced by the ERA-40 reanalysis and the CMIP5 GCMs is able to reproduce the inter-annual MAR$\mathrm{ERA}_{\text {Int }}$ variability (investigated here through the standard deviation) of the 1980-1999 GrIS melt. Moreover, the annual melt trends are generally consistent between the different MAR runs for this period, and the average biases are significantly lower than the MAR-ERA $\mathrm{Int}_{\text {standard deviation. As- }}$ sessing the averaged NET fluxes and SEB components over the $\mathrm{MSK}_{\text {melt }}$ specific to each MAR run generally leads to the same conclusions (see Table 3).

Figure 3 shows non-significant spatial differences (lower than 2 standard deviations) in the annual melt pattern simulated between the MAR-ERA Int and the other MAR runs over 1980-1999. Furthermore, the skill scores of these simulations, which represent a normalized root mean square deviation of the multi-annual averaged modelled field from the multi-annual averaged MAR-ERA $A_{\text {Int }}$ field rescaled between 0 and 1 (with 1 as the perfect match), are lower than the annual standard deviation skill score (0.73) of MAR-ERA Int. Refer to Franco et al. (2012) for more details about this skill score methodology. The MAR-ERA 40 simulation shows negative anomalies in the western ablation zone (Fig. 3a), because the ERA-40 reanalysis is colder in summer than the ERA-Interim. The discrepancies between our reference MAR simulation (MAR-ERA Int $)$ and MAR-CAN histo $_{\text {, MAR- }}$

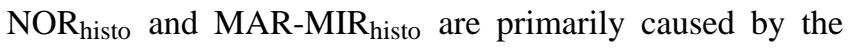
GCM biases with respect to the ERA-Interim over 19801999. CanESM2 is too warm in summer over the northwestern ice sheet, and its atmospheric circulation does not enable a sufficient moisture advection into this region (Fettweis et al., 2012a). Therefore, MAR-CAN $\mathrm{N}_{\text {histo makes the }}$ bare ice appear sooner (which enhances the melt) because of the underestimation of precipitation in this part of the GrIS compared to MAR-ERA Int (Fig. 3b). Conversely, CanESM2 
Table 3. Annual melt amount $\left(\mathrm{Gt} \mathrm{yr}^{-1}\right)$ of the GrIS over the 1980-1999 period from different MAR simulations, and the melt energy flux (NET) and SEB components $\left(\mathrm{W} \mathrm{m}^{-2}\right.$ ) averaged over the 1980-1999 MSK $_{\text {melt }}$ specific to each MAR run.

\begin{tabular}{|c|c|c|c|c|c|}
\hline & MAR-ERA $_{\text {Int }}$ & MAR-ERA40 & MAR-CAN histo & MAR-NOR & MAR-MIR $_{\text {histo }}$ \\
\hline $\operatorname{Melt}\left(\mathrm{Gt} \mathrm{yr}^{-1}\right)$ & 455.25 & 435.14 & 422.31 & 404.75 & 453.40 \\
\hline Stdev & 93.36 & 98.22 & 116.44 & 63.31 & 103.79 \\
\hline Trend & 4.08 & 6.16 & 8.65 & 0.61 & 3.56 \\
\hline $\operatorname{NET}\left(\mathrm{W} \mathrm{m}^{-2}\right)$ & 20.84 & 19.56 & 21.02 & 18.42 & 21.41 \\
\hline Stdev & 4.59 & 4.77 & 6.19 & 3.26 & 5.67 \\
\hline Trend & 0.18 & 0.28 & 0.46 & 0.07 & 0.16 \\
\hline $\mathrm{SW}_{\text {net }}\left(\mathrm{W} \mathrm{m}^{-2}\right)$ & 75.83 & 73.74 & 71.34 & 73.50 & 75.13 \\
\hline Stdev & 4.97 & 4.89 & 6.44 & 4.40 & 6.37 \\
\hline Trend & 0.20 & 0.22 & 0.36 & 0.09 & 0.04 \\
\hline $\mathrm{LW}_{\text {net }}\left(\mathrm{W} \mathrm{m}^{-2}\right)$ & -61.57 & -60.37 & -57.10 & -61.59 & -60.91 \\
\hline Stdev & 2.12 & 2.10 & 2.28 & 2.39 & 3.02 \\
\hline Trend & -0.06 & 0.01 & 0.00 & 0.00 & 0.09 \\
\hline $\mathrm{SHF}\left(\mathrm{W} \mathrm{m}^{-2}\right)$ & 9.86 & 9.20 & 9.27 & 9.50 & 10.19 \\
\hline Stdev & 1.03 & 1.00 & 2.11 & 1.27 & 1.67 \\
\hline Trend & 0.04 & 0.03 & 0.09 & -0.04 & 0.02 \\
\hline $\operatorname{LHF}\left(\mathrm{W} \mathrm{m}^{-2}\right)$ & -3.28 & -3.01 & -2.50 & -2.99 & -3.00 \\
\hline Stdev & 0.29 & 0.24 & 0.45 & 0.38 & 0.55 \\
\hline Trend & 0.00 & 0.01 & 0.01 & 0.01 & 0.01 \\
\hline
\end{tabular}

underestimates the air temperature in the southern GrIS, which explains the negative melt discrepancies in MAR (Fig. 3b). Similarly, NorESM1-M is too cold in summer at the MAR boundaries with respect to the ERA-Interim (Fettweis et al., 2012a), which causes the MAR model to simulate lower melting rates in the ablation zone than MARERA $_{\text {Int }}$ (Fig. 3c). Finally, MIROC5 underestimates (overestimates) the air temperature in the southern (northern) GrIS, inducing related negative (positive) melt anomalies in the

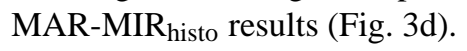

\section{Projected melt anomalies of the GrIS}

Exceptional melt events of the GrIS have been highlighted with a focus on the close relationship between the melt and the near-surface air temperatures (TAS) (Mote, 2007; Tedesco, 2007). The different MAR simulations performed in this study (listed in Table 1) allow the assessment of the response of GrIS meltwater production to a TAS increase, independent of the CMIP5 RCP scenarios. By comparing the annual anomalies of total GrIS melt and summer TAS averaged over the ice sheet throughout the present-day period and the 21st century, it appeared that the increase of the annual melting rate is strongly correlated $(R=0.943)$ but nonlinearly related to the TAS anomalies (Fig. 4a). In addition, this relationship seems to be independent of the forcing fields used in this study, but all the MAR runs simulate comparable melt rates for current climate conditions. Such an expo-
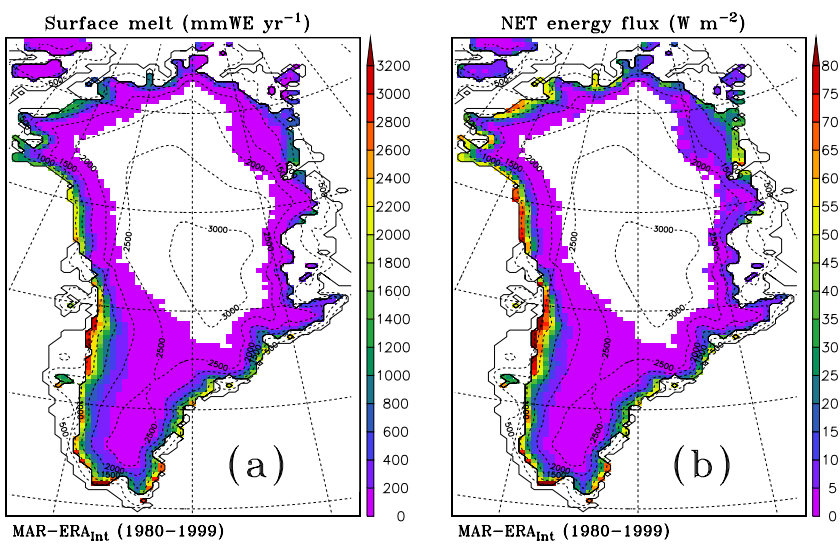

Fig. 2. (a) Average annual melt $\left(\mathrm{mm} \mathrm{WE} \mathrm{yr}^{-1}\right)$ of MAR-ERAInt over the 1980-1999 period. The surface height (m) is drawn in dashed line. (b) Average net energy flux $\left(\mathrm{W} \mathrm{m}^{-2}\right)$ available at the surface of the ice sheet for enabling the melt in (a).

nential relationship suggests that if melt rate is over- or underestimated for the current climate, the melt response to air temperature increases is different, as shown by Fettweis et al. (2012a).

The projected Greenland warming also impacts the melt season. A comparison between the 1980-1999 MAR$\mathrm{CAN}_{\text {histo }}$ and the 2080-2099 MAR-CAN 45 and MAR$\mathrm{CAN}_{85}$ simulations reveals that the melt season is expected to start approximately two weeks sooner at the end of the 21 st 

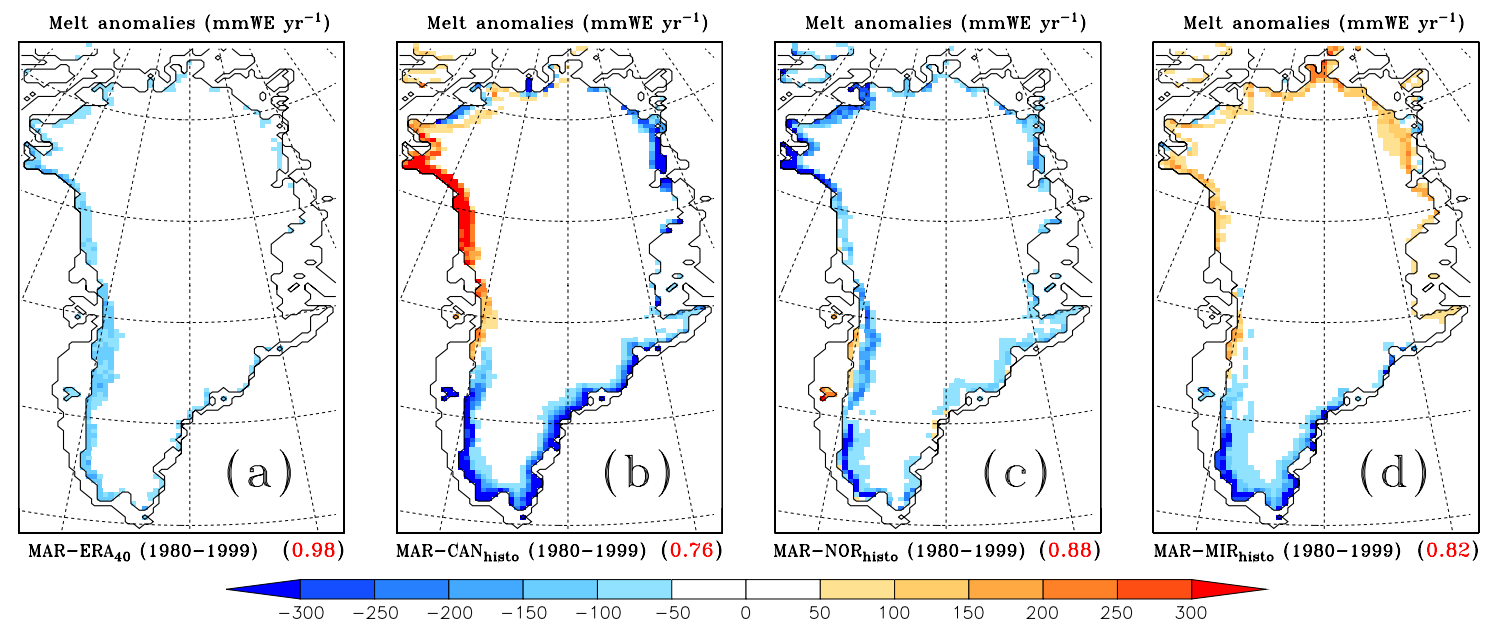

MAR-CAN histo $(1980-1999)(0.76)$

MAR-NOR histo $(1980-1999)(0.88)$

MAR-MIR histo $(1980-1999)(0.82)$

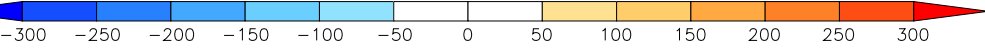

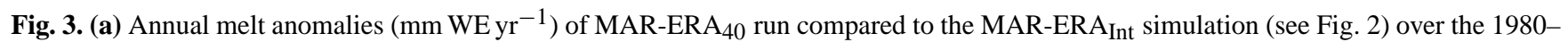
1999 period. In the bottom right side of the view, in red, is the melt skill score of MAR-ERA 40 compared to MAR-ERA Int. $(\mathbf{b}-\mathbf{d})$ The same as (a), but for the MAR-CAN histo MAR-NOR $_{\text {histo }}$ and MAR-MIR histo $_{\text {simulations. }}$

century compared to the present-day climate and that significant melt events could still occur from two to three weeks after the end of the present-day melt season (Fig. S2a). The different factors explaining this offset will be developed further in this study. However, the MAR model projects no significant melt event during winter, even for the most extreme scenarios.

These GrIS melting rates, increased due to higher temperatures, are also attended by an enlarged melt area on the ice sheet, as suggested by Fig. 4b, where the anomalies of annual mean temperature and annual cumulated melt extents (obtained by summing throughout the year all the daily areas with melting rate higher than $1 \mathrm{~mm} \mathrm{WE} \mathrm{day}{ }^{-1}$ ) are highly correlated $(R=0.968)$. According to Table 2 , the maximum GrIS melt extent covers the entire ice sheet at the end of the 21 st century for the most pessimistic scenarios. Nonetheless, the cumulated melt extents are rather linearly related to the TAS anomalies (Fig. 4b), while the melting rate is gradually amplified (Fig. 4a).

Unlike the melt extent, the bare ice extent expands nonlinearly with increasing temperatures $(R=0.920)$ (Fig. 4c). This suggests that the extension of the bare ice area resulting from the positive surface albedo feedback could be responsible for the amplified melt anomalies with increasing temperatures in the future. Indeed, the albedo of melting snow covered surface remains high $(\sim 0.70)$, but drops when the bare ice appears (albedo of $\sim 0.45$ ) after the removing of the winter snowpack.

\section{SEB component contributions to melt anomalies}

Partitioning the net energy flux received at the surface of the ice sheet during melt within the SEB components makes it possible to investigate their different responses to Green- land warming and to estimate their relative contributions to the increased GrIS melting rate induced by such temperature changes. First the annual anomalies of the SEB components to the 1980-1999 period are compared on MSK $_{\text {melt }}$ to the related TAS anomalies by using outputs from MAR, forced by CanESM2, NorESM1-M and MIROC5 (Fig. 5a) for past simulations (1980-1999) and future projections (2080-2099). The same comparison is also carried out for the present-day climate modelled by MAR using the ERAInterim (1979-2011) and ERA-40 (1979-1999) reanalyses as forcing fields (Fig. 5b). The relative contributions of the SEB components to NET anomalies, and hence to GrIS melt energy anomalies, are then estimated between the 2080-2099 projections and the 1980-1999 results on the 1980-1999 masks of daily melt events (MSK melt (Table 4a). Figure 5 on $\mathrm{MSK}_{\text {melt }}$ can be compared to the same experiment carried out on an annually varying mask of melt events (Fig. S3).

\subsection{Net shortwave flux $\left(\mathrm{SW}_{\text {net }}\right)$}

According to the different future projections investigated here (Table 4a), more than half of the 2080-2099 NET anomalies to the present-day climate are explained by the $\mathrm{SW}_{\text {net }}$ increase $(53.13 \%)$ simulated by MAR. The solar energy absorbed at the ice sheet surface has already been highlighted as the dominant factor controlling the melt variability during present-day summer in the ablation area of the western GrIS (van den Broeke et al., 2008, 2011). Nevertheless, partitioning this $\mathrm{SEB}$ component in $\mathrm{SW}_{\mathrm{alb}}$ and $\mathrm{SW}_{\mathrm{swd}}$ (i.e. SW $_{\text {net }}$ calculated for the 2080-2099 period by keeping the average 1980-1999 SWD and ALB constant, respectively) reveals that the surface albedo anomalies contribute $65.12 \%$ to the NET increase compared to the present-day climate, while the SWD decrease causes the influence of albedo to 

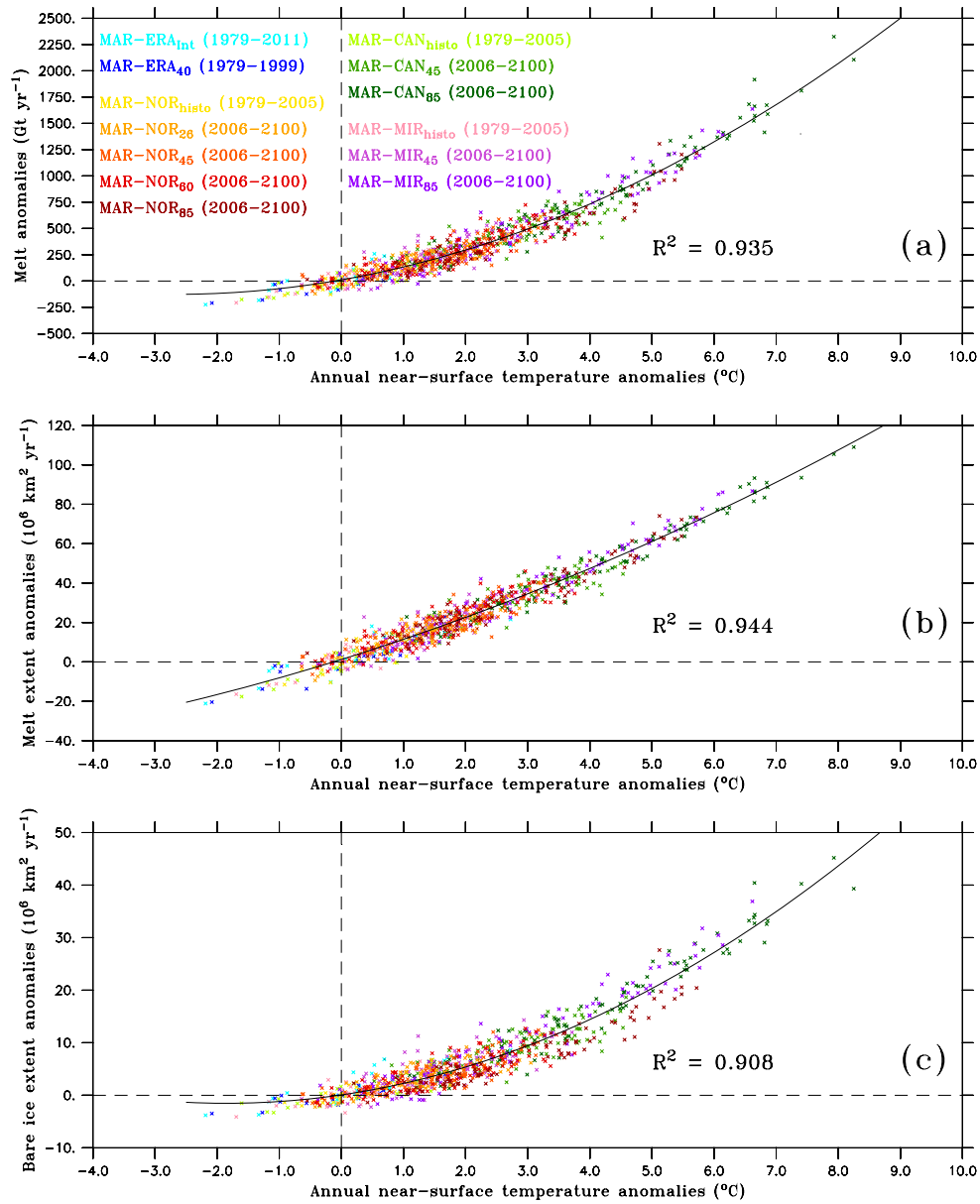

Fig. 4. (a) Annual melt anomalies $\left(\mathrm{Gt} \mathrm{yr}^{-1}\right)$ from the GrIS according to the annual near-surface air temperature anomalies $\left({ }^{\circ} \mathrm{C}\right)$, for the different MAR simulations forced by the reanalyses and the CMIP5 GCMs, with regression drawn in a solid black line. All the annual anomalies are related to the 1980-1999 average outputs provided by MAR forced with the same forcing fields. (b) The same as (a), but for the annual anomalies of cumulated daily melt extents $\left(10^{6} \mathrm{~km}^{2} \mathrm{yr}^{-1}\right)$ on the GrIS, based on significant melt rates higher than $1 \mathrm{~mm}$ WE day ${ }^{-1}$. (c) The same as (b), but for the annual anomalies of cumulated daily bare ice extents $\left(10^{6} \mathrm{~km}^{2} \mathrm{yr}^{-1}\right)$ on the GrIS.

be slightly lessened $(-6.91 \%)$. This means that the warmer the projected scenario, the more the surface albedo feedback is attenuated (Table $4 \mathrm{a}$ ). Nonetheless, the average contribution of $\mathrm{SW}_{\text {swd }}(-6.91 \%)$ is almost non-significant compared to the standard deviation of the $\mathrm{SW}_{\text {net }}$ contribution $(6.21 \%)$ (see Table 4a).

The comparison of the annual $\mathrm{SW}_{\text {alb }}$ and $\mathrm{SW}_{\text {swd }}$ versus the TAS anomalies simulated by MAR forced by different CMIP5 scenarios (Fig. 5a) confirms that $\mathrm{SW}_{\mathrm{alb}}$ is the most sensitive SEB component to an increasing air temperature with a strong correlation $(R=0.947)$ independent of the forcing fields used here. While the $\mathrm{SW}_{\mathrm{swd}}$ decrease is linearly related to the TAS changes $(R=-0.495)$, the positive $\mathrm{SW}_{\mathrm{alb}}$ anomalies are projected to be strongly amplified by GrIS warming due to the positive feedback of the ice sheet albedo (Box et al., 2012). This positive albedo feedback can also be observed in the present-day simulations performed by MAR forced with reanalyses (Fig. 5b), and explains most of the non-linearity between the temperature and melting rate changes over current climate (Fig. $4 \mathrm{a}$ ): higher temperatures contribute to the decrease of the surface albedo by improving snow metamorphism, and consequently snow grain growth (Wiscombe and Warren, 1980; Dozier et al., 1981), which in turn amplifies the net energy flux (through the increase of absorbed solar radiation) available at the ice sheet surface to enable the melt. In addition, increasing temperature induces heightened melt of the winter snowpack and then an early appearance of the bare ice zone.

According to Fig. 5a, SWD is projected to decrease slightly with the TAS increase. Indeed, the MAR future projections tend to reinforce the cloudiness over Greenland with respect to future higher temperatures $(R=0.898)$, because there is more evaporation above the ocean, and the atmosphere can contain more moisture, which decreases the solar radiation passing through the atmosphere towards the surface (Fig. S4). But the MAR model forced by the ECMWF 
Table 4. (a) Relative contribution (\%) of each SEB component to the NET anomalies of the 2080-2099 period compared to the 19801999 period, according to the forcing fields. Each future projection was compared to the 1980-1999 average of the present-day simulation performed with the same GCM as forcing fields, on the related 1980-1999 MSK melt. (b) The same as (a), but on the related 1980-1999 MSK $_{\text {ice. }}$.

\begin{tabular}{lrrrrrrrr}
\hline \multicolumn{8}{c}{ (a) Relative contribution (\%) of the SEB components on $1980-1999$ MSK $_{\text {melt }}$} \\
\hline & SW $_{\text {net }}$ & LW $_{\text {net }}$ & SHF & LHF & SW $_{\text {alb }}$ & SW $_{\text {swd }}$ & LWD & LWU \\
MAR-CAN $_{45}$ & 56.37 & 11.45 & 26.49 & 5.69 & 66.69 & -8.15 & 47.92 & -36.46 \\
MAR-CAN $_{85}$ & 46.49 & 16.18 & 29.81 & 7.51 & 53.86 & -9.44 & 40.31 & -24.12 \\
MAR-NOR $_{26}$ & 60.12 & 9.31 & 28.56 & 2.01 & 74.26 & 0.15 & 59.96 & -50.65 \\
MAR-NOR $_{45}$ & 57.95 & 12.85 & 26.10 & 3.10 & 71.55 & -3.32 & 59.51 & 46.67 \\
MAR-NOR $_{60}$ & 51.69 & 18.38 & 24.52 & 5.41 & 65.70 & -8.21 & 62.73 & -44.36 \\
MAR-NOR $_{85}$ & 43.21 & 23.82 & 26.23 & 6.74 & 56.39 & -11.50 & 59.64 & -35.82 \\
MAR-MIR $_{45}$ & 58.97 & 18.31 & 17.22 & 5.50 & 73.38 & -6.16 & 57.08 & -38.77 \\
MAR-MIR 85 & 50.23 & 17.85 & 25.14 & 6.79 & 59.08 & -8.61 & 45.15 & -27.31 \\
\hline Mean & 53.13 & 16.02 & 25.51 & 5.35 & 65.12 & -6.91 & 54.04 & -38.02 \\
Stdev & 6.21 & 4.64 & 3.77 & 1.89 & 7.89 & 3.72 & 8.34 & 9.18 \\
\hline
\end{tabular}

(b) Relative contribution (\%) of the SEB components on 1980-1999 MSK $_{\text {ice }}$

\begin{tabular}{lrrrrrrrr}
\hline & SW $_{\text {net }}$ & $\mathrm{LW}_{\text {net }}$ & $\mathrm{SHF}$ & $\mathrm{LHF}$ & $\mathrm{SW}_{\text {alb }}$ & $\mathrm{SW}_{\text {swd }}$ & LWD & LWU \\
MAR-CAN $_{45}$ & 1.91 & 31.62 & 54.22 & 12.25 & 10.42 & -5.48 & 39.54 & -7.91 \\
MAR-CAN $_{85}$ & 0.37 & 30.94 & 54.61 & 14.08 & 5.90 & -4.06 & 36.94 & -6.00 \\
MAR-NOR $_{26}$ & 10.26 & 25.07 & 56.23 & 8.45 & 18.37 & -0.53 & 32.77 & -7.70 \\
MAR-NOR $_{45}$ & 13.45 & 25.11 & 53.92 & 7.52 & 16.88 & 3.77 & 32.95 & -7.84 \\
MAR-NOR $_{60}$ & 4.46 & 33.28 & 51.12 & 11.14 & 14.28 & -4.60 & 41.20 & -7.92 \\
MAR-NOR $_{85}$ & -3.30 & 37.71 & 52.10 & 13.49 & 9.89 & -9.54 & 45.42 & -7.71 \\
MAR-MIR $_{45}$ & 22.14 & 26.41 & 39.12 & 12.34 & 20.79 & 8.28 & 33.31 & -6.91 \\
MAR-MIR & 3.66 & 31.88 & 50.36 & 14.11 & 9.82 & -3.71 & 38.27 & -6.40 \\
\hline Mean & 6.62 & 30.25 & 51.46 & 11.67 & 13.30 & -1.99 & 37.55 & -7.30 \\
Stdev & 8.23 & 4.44 & 5.35 & 2.50 & 5.10 & 5.66 & 4.51 & 0.76 \\
\hline
\end{tabular}

reanalyses instead simulates increased SWD with positive TAS anomalies (Fig. 5b), due to a reduced cloud cover observed in the present-day climate over Greenland induced by more persistent anticyclonic circulations during the recent summers (Box et al., 2012; Hanna et al., 2012; Overland et al., 2012). These observed changes in the general circulation linked to the North Atlantic Oscillation (NAO) are nevertheless not simulated by the CMIP5 GCMs (Belleflamme et al., 2012; Fettweis et al., 2012b), which explains the opposite trends between SWD and TAS since 1979 (Fig. 5a, b). Consequently, the MAR simulations performed with the CMIP5 GCMs as forcing fields underestimate the impact of the surface albedo feedback (and hence the current melt increase; Fettweis et al., 2012b) with respect to the reanalysesforced MAR runs for the same TAS increase (see the dashed and solid purple lines, respectively, in Fig. 5b).

\subsection{Sensible heat flux (SHF)}

The second most important contribution in the SEB changes is provided by the positive SHF anomalies $(25.51 \%)$, as presented in Table 4a. Indeed, as the temperature inversions are almost persistent over the GrIS, SHF generally repre- sents a significant energy source during the melt season (van den Broeke et al., 2008, 2011). Figure 5a suggests that the SHF changes from the GrIS are gradually strengthened with the increasing temperature $(R=0.911)$, as also observed for the present-day climate modelled by reanalyses-forced MAR (Fig. 5b). This is mainly due to the enhancement of warm air advection induced by the large-scale atmospheric circulation, occurring in marginal parts of the GrIS under a warmer climate.

Furthermore, in the western part of Greenland, barrier winds driven by the horizontal gradient of air temperature between the tundra and the GrIS can be advected eastwards on the ice sheet by the south-westerly large-scale flow, contributing to the transport of warm air on the ice sheet surface and consequently enhancing SHF (van den Broeke and Gallée, 1996). As the tundra is projected to warm more rapidly than the surrounding ice sheet (Fig. S5a-d), the thermal contrast would be strengthened, resulting in stronger barrier winds along the edge of the ice sheet (Fig. S5e-h) and then in an enhanced warm air advection over the surface of the western GrIS.

The SHF increase with respect to positive TAS anomalies is less important than $\mathrm{SW}_{\text {alb }}$ (Fig. 5), because SHF depends 

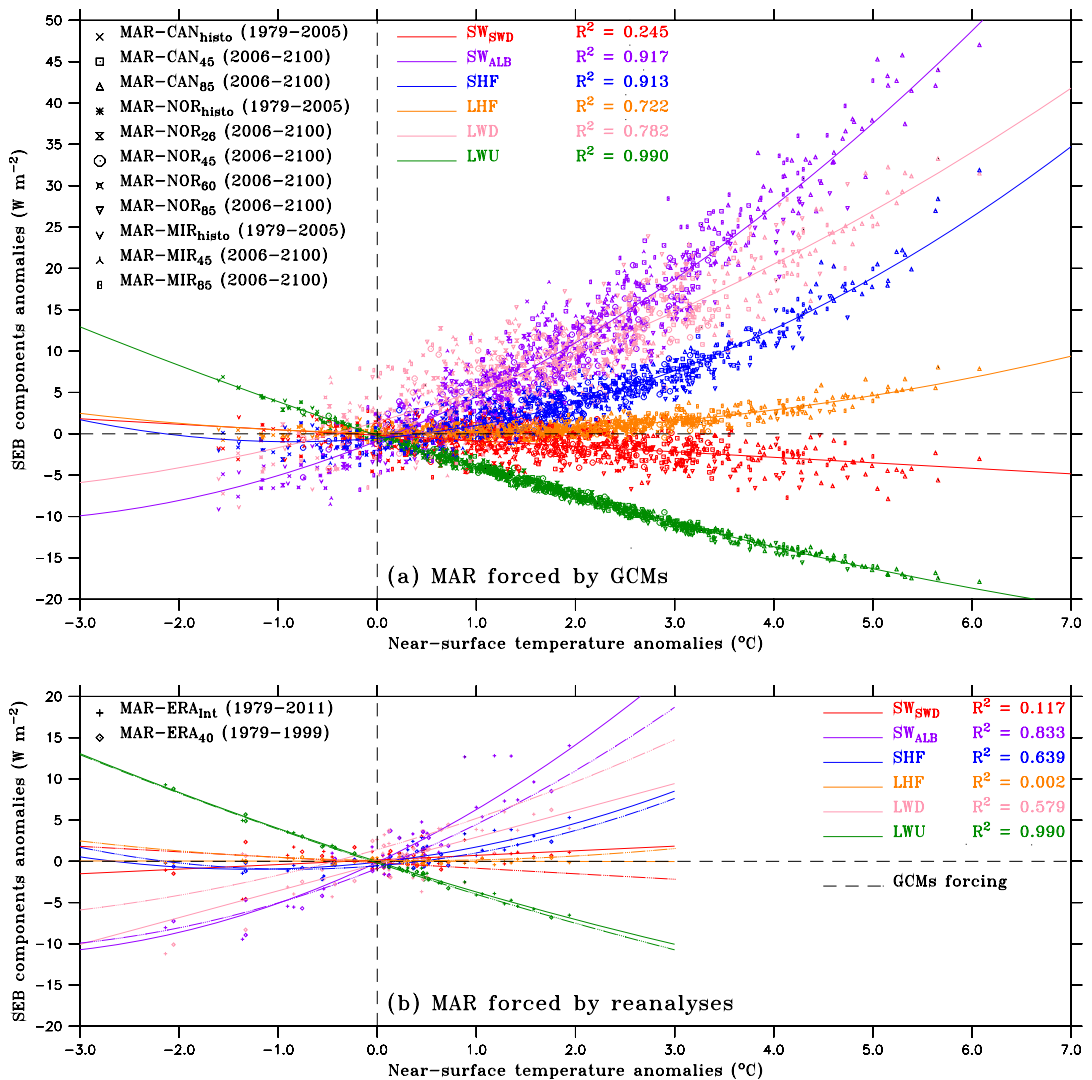

Fig. 5. (a) SEB component anomalies $\left(\mathrm{W} \mathrm{m}^{-2}\right.$ ) from the GrIS according to the near-surface air temperature anomalies $\left({ }^{\circ} \mathrm{C}\right)$ for the MAR simulations forced by CMIP5 GCMs, with regressions drawn in solid lines. All the anomalies are related to the 1980-1999 average outputs provided by MAR forced with the same forcing fields on the 1980-1999 MSK $_{\text {melt }}$. (b) The same as (a), but for the MAR simulations forced by the ERA-Interim and ERA-40 reanalyses, with the regressions from (a) drawn in dashed lines.

strongly on air temperature gradients, and the ice sheet surface rises rapidly from the margins towards the centre, impeding the warm air from penetrating further inland. Moreover, positive SHF anomalies (due to increased warm air advection) add more melt energy to the ice sheet surface, which in turn reduces the albedo and then contributes to strengthening the absorbed solar radiation $\left(\mathrm{SW}_{\text {net }}\right)$. However, SHF appears to be the SEB component with the highest relative increase between the 1980-1999 and 2080-2099 periods (Table S1 in Supplementary Materials): from +39.89 to $+211.79 \%$ of SHF anomalies according to the RCP scenario, compared to an increase from +10.85 to $+42.94 \%$ for the $\mathrm{SW}_{\text {net }}$.

\subsection{Net longwave flux $\left(\mathrm{LW}_{\text {net }}\right)$}

The increased $\mathrm{LW}_{\text {net }}$ represents a rather limited contribution to the projected NET anomalies $(16.02 \%)$, mainly because the positive LWD anomalies $(54.04 \%)$ are partly counterbalanced by the reinforced LWU $(-38.02 \%)$ (Table $4 a)$. Indeed, as the atmosphere is warmer and the cloudiness increases, the longwave radiation towards the surface is strengthened with respect to the positive TAS anomalies $(R=0.877)$, as drawn in Fig. 5a and b. Nevertheless, higher temperatures warm the surface and then enhance the longwave radiation emitted by the surface (LWU) $(R=-0.992)$, partly counterbalancing the LWD anomalies and hence impeding a large $\mathrm{LW}_{\text {net }}$ increase.

According to the MAR outputs, the LWD and LWU anomalies are generally in balance over MSK $_{\text {melt }}$ for small TAS changes lower than $+2{ }^{\circ} \mathrm{C}$ (Fig. 5a and b). For a larger warming, the pixels where melt occurs every time of the day are more frequent. Given that the surface temperature of melting snow is limited to $0{ }^{\circ} \mathrm{C}$, higher temperatures do not increase LWU, while the incoming longwave radiation (LWD) carries on to be enhanced by a warmer atmosphere, resulting in more positive $\mathrm{LW}_{\text {net }}$ anomalies.

\subsection{Latent heat flux (LHF)}

Finally, the contribution of LHF changes induced by higher air temperatures ( $R=0.744)$ to the NET increase by the end of the 21 st century would be almost negligible compared to the other SEB components $(5.35 \%)$. LHF is generally defined as an energy source around the GrIS margins during 
melt but, in contrast, as an energy sink in the centre parts of the ice sheet (van den Broeke et al., 2008). Indeed, the little moisture contained in the air over the central GrIS enables evaporation and sublimation and hence contributes to reducing the melt energy at the surface, while areas around the ice sheet margins are characterized by a warmer air generally containing more moisture, so that LHF adds to energy available for surface melt in the border regions of the ice sheet.

According to Table 3, LHF averaged over MSK $_{\text {melt }}$ appears to be an energy sink during the present-day climate, but Fig. 5 shows positive LHF anomalies with increasing air temperatures simulated by the MAR model. These results suggest that LHF is expected to become less of an energy sink in a future warmer climate and to turn eventually into an average energy source over $\mathrm{MSK}_{\text {melt }}$, mainly because of the projected warmer air and the significant addition of moisture brought to the low-elevation ice sheet.

\section{Spatial distribution of SEB component anomalies}

A spatial comparison between the 2080-2099 MAR-CAN 85 and 1980-1999 MAR-CAN ${ }_{\text {histo }}$ simulations reveals that the projected highest NET anomalies (up to $+80 \mathrm{~W} \mathrm{~m}^{-2}$, which represents an increase by more than $150 \%$ of the 1980-1999 NET) are essentially located in the western and northern border areas of the GrIS (Fig. 6a).

According to Fig. 6, these large marginal anomalies are mainly due to the increased $\mathrm{SW}_{\text {net }}$ and particularly by the decreased albedo (evaluated here through $\mathrm{SW}_{\mathrm{alb}}$ ) in areas where higher melting rates cause the appearance of bare ice (as shown in Fig. 6b, e, f). Therefore, the strongest projected NET anomalies occur in areas where the bare ice is projected to appear and which are covered by snow in the present-day climate. This explains why most of the changes are not located in the closest vicinity of the ice sheet margin, which is already covered for part of the time by bare ice in the presentday climate.

Figure 6 also shows that the equilibrium line altitude (ELA) from 2080-2099 MAR-CAN 85 simulations is strongly pushed aside towards the centre of the ice sheet, especially in the western and northern parts of Greenland. This comparison highlights that the accumulation zone located near the present-day ELA could turn into an ablation zone. Conversely, the offset of the 2080-2099 ELA along the eastern GrIS margin is quite limited by the huge topography of these areas (and hence by the strong horizontal gradients of temperature), impeding the ablation zone from significantly spreading further inland over the ice sheet.

As mentioned previously, the projected SHF anomalies contribute significantly to the 2080-2099 NET increase over the GrIS (Table 4a). Nevertheless, this contribution is essentially confined to the present-day ablation zone (Fig. 6d). Moreover, the projected decrease of the sea ice concentration in the Arctic region (Stendel et al., 2008), already observed in the present-day climate (Serreze et al., 2007; Comiso et al., 2008), enhances the warm air advection in the border parts of Greenland, especially along the northern coast. Consequently, the SHF increase related to projected GrIS warming is expected to strengthen the melt intensity in the ablation zone of the present-day climate, but unlike the reduced surface albedo would not significantly contribute to enlarging the melt extent in the future.

To a lesser extent, the NET changes along the western and northern GrIS margins are also due to small positive $\mathrm{LW}_{\text {net }}$ anomalies (Fig. 6c). As explained previously, the LWD strengthening over the GrIS (Fig. 6g) is not entirely counterbalanced by the increased LWU (Fig. 6h) in the border areas where days without night refreezing are already modelled over 1980-1999.

The projected spatial LHF changes (not shown here) are confined to within $\pm 10 \mathrm{~W} \mathrm{~m}^{-2}$, and hence can be considered as an almost negligible contribution to the increased melt energy compared to the other SEB components.

Projected changes in precipitation regimes in Greenland also influence the spatial distribution of the SEB component anomalies. Although the future simulations produce heavier winter snowfall (Fig. S2d), during the melt season the projected snowfall (temporally increasing the surface albedo) is highly reduced, and the rainfall strongly increased compared to the present-day climate (Fig. S2d). However, these precipitation anomalies are not homogeneously distributed over the GrIS: while the annual snowfall is mainly strengthened in the central parts of the ice sheet (Fig. S6a, e), significant parts of the snowfall in south Greenland are turned into heavy rainfall (Fig. S6b, f). Such increased rainfall contributes to lowering the surface albedo (see Sect. 7 and Fig. S2c, d).

\section{Surface albedo}

As already highlighted in Sects. 5 and 6, the summer surface albedo is projected to be strongly reduced in the present-day percolation zone of the GrIS by up to -0.20 for 2080-2099 compared with 1980-1999 (Fig. S7). According to the MAR future simulations, the surface albedo decrease over $\mathrm{MSK}_{\text {melt }}$ induced by the projected Greenland warming (Fig. S8a) is also amplified by fewer snowfall events and more rainfall events (Fig. S8b, c). This results in an enlargement of the area covered by lower-albedo bare ice in the place of higheralbedo dry/melting snow, which enhances surface solar heating and accelerates melt.

The summer surface albedo over the central GrIS is investigated for the dry snow zone, which is limited here to pixels higher than $2000 \mathrm{~m}$ elevation and to areas where the annual melt averaged over 1980-1999 is lower than $5 \mathrm{~mm}$ WE (defined here as $\left.\mathrm{MSK}_{\text {centre}}\right)$. Over this mask, the MAR model simulates positive surface albedo anomalies with increasing temperatures compared to the 1980-1999 results (Fig. 7a), due to heavier modelled snowfall over the central ice sheet 

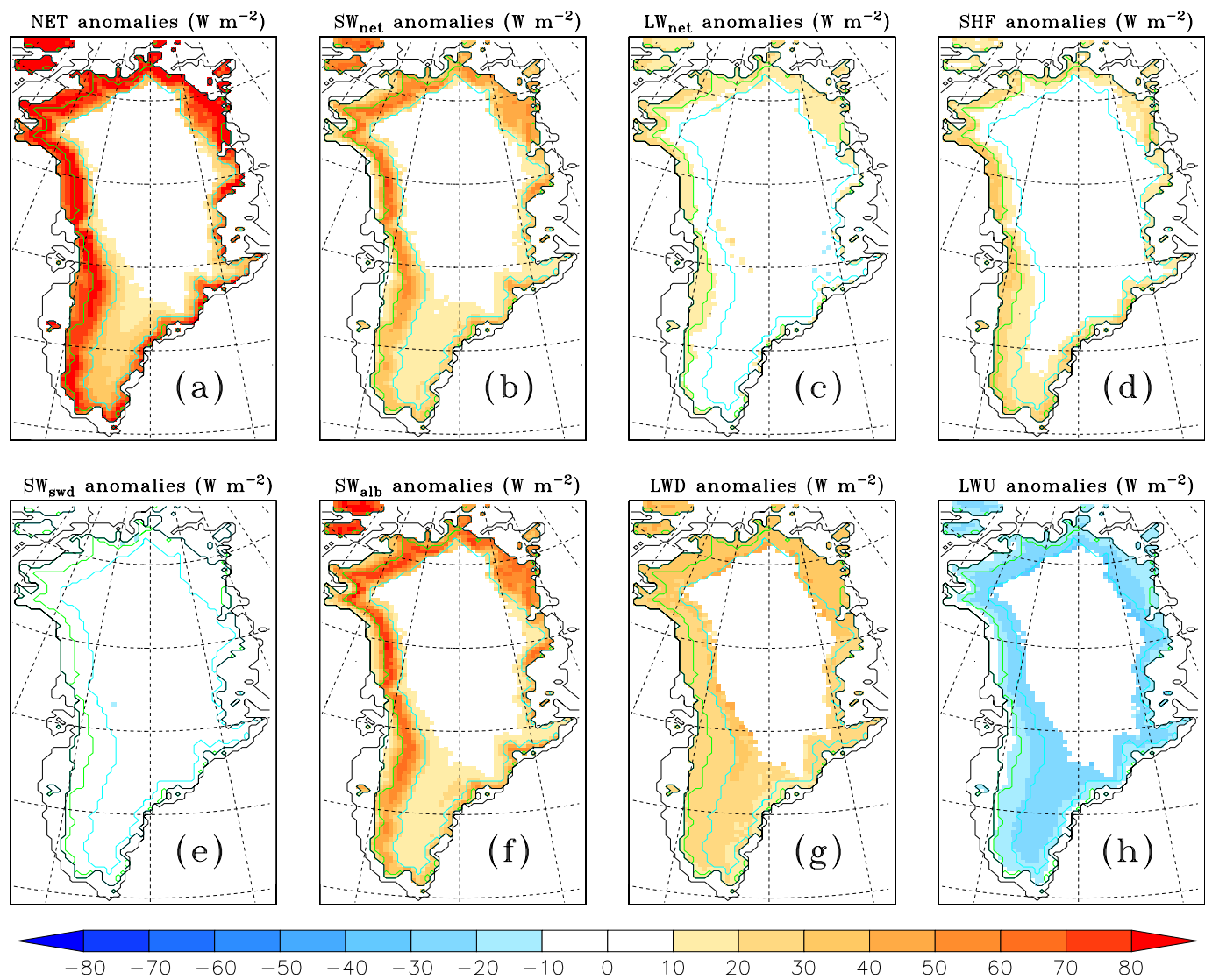

Fig. 6. (a) Net energy flux (NET) anomalies $\left(\mathrm{W} \mathrm{m}^{-2}\right.$ ) of the 2080-2099 MAR-CAN 85 simulation over the GrIS, compared to the 1980-

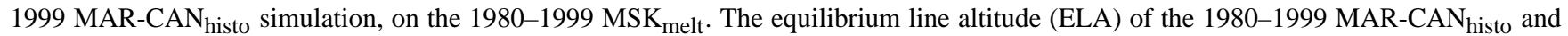
2080-2099 MAR-CAN 85 simulations are drawn in a solid green line and a solid blue line, respectively. (b-h) The same as (a), but for the SEB component anomalies $\left(\mathrm{W} \mathrm{m}^{-2}\right)$.

(Fig. 7b) (Box et al., 2012). Indeed, more frequent snow depositions induced by higher temperatures over $\mathrm{MSK}_{\text {centre }}$ lead to a rise in the surface albedo of the GrIS. However, larger Greenland warming (higher than $1.5^{\circ} \mathrm{C}$ ) in the central ice sheet would enable the surface melt, which decreases the surface albedo (Fig. 7c). Such enhanced surface melt rapidly counterbalances the albedo increase induced by heavier snowfall, and eventually surpasses the snowfall negative feedback for larger TAS anomalies (more than $4{ }^{\circ} \mathrm{C}$ ) by lowering the surface albedo. Nonetheless, the projected 20802099 surface albedo anomalies with respect to $1980-1999$ are non-significant (lower than 0.05) over the central ice sheet.

\section{SEB component anomalies over bare ice area}

The strengthened anomalies of the bare ice extent have been proven very important to explaining the non-linearity between the simulated melt and temperature increase (see Sect. 4). Furthermore, the spatial distribution assessment of the SEB component anomalies suggested behaviour over the bare ice areas quite different to that simulated over the melt areas (see Sect. 6). Therefore, the response of the SEB components to GrIS warming is investigated here for the bare ice areas specifically, by carrying out the same experiment as in Sect. 5, but on the 1980-1999 MSK $_{\text {ice }}$, taking into account the melting bare ice area only.

The contribution of the $\mathrm{SW}_{\text {net }}$ anomalies to the NET 2080-2099 anomalies is strongly reduced on $\mathrm{MSK}_{\text {ice }}$ (from $53.13 \%$ to $6.62 \%$ ), because the surface albedo of the mean present-day melting bare ice extent has already reached its minimum in the present-day climate. According to Fig. 8, the influence of the reduced surface albedo (evaluated here through $\mathrm{SW}_{\mathrm{alb}}$ ) on the positive $\mathrm{SW}_{\text {net }}$ anomalies over the bare ice progressively decreases with increasing temperature, and tends to stabilize for TAS anomalies higher than $+2{ }^{\circ} \mathrm{C}$ compared to $1980-1999$.

As the surface temperature on the bare ice zone is already limited to $0{ }^{\circ} \mathrm{C}$ over the current climate, the low increase of longwave emission from the surface (LWU) due to the positive TAS anomalies does not counterbalance the enhanced LWD (Fig. 8), making the positive $\mathrm{LW}_{\text {net }}$ anomalies the 

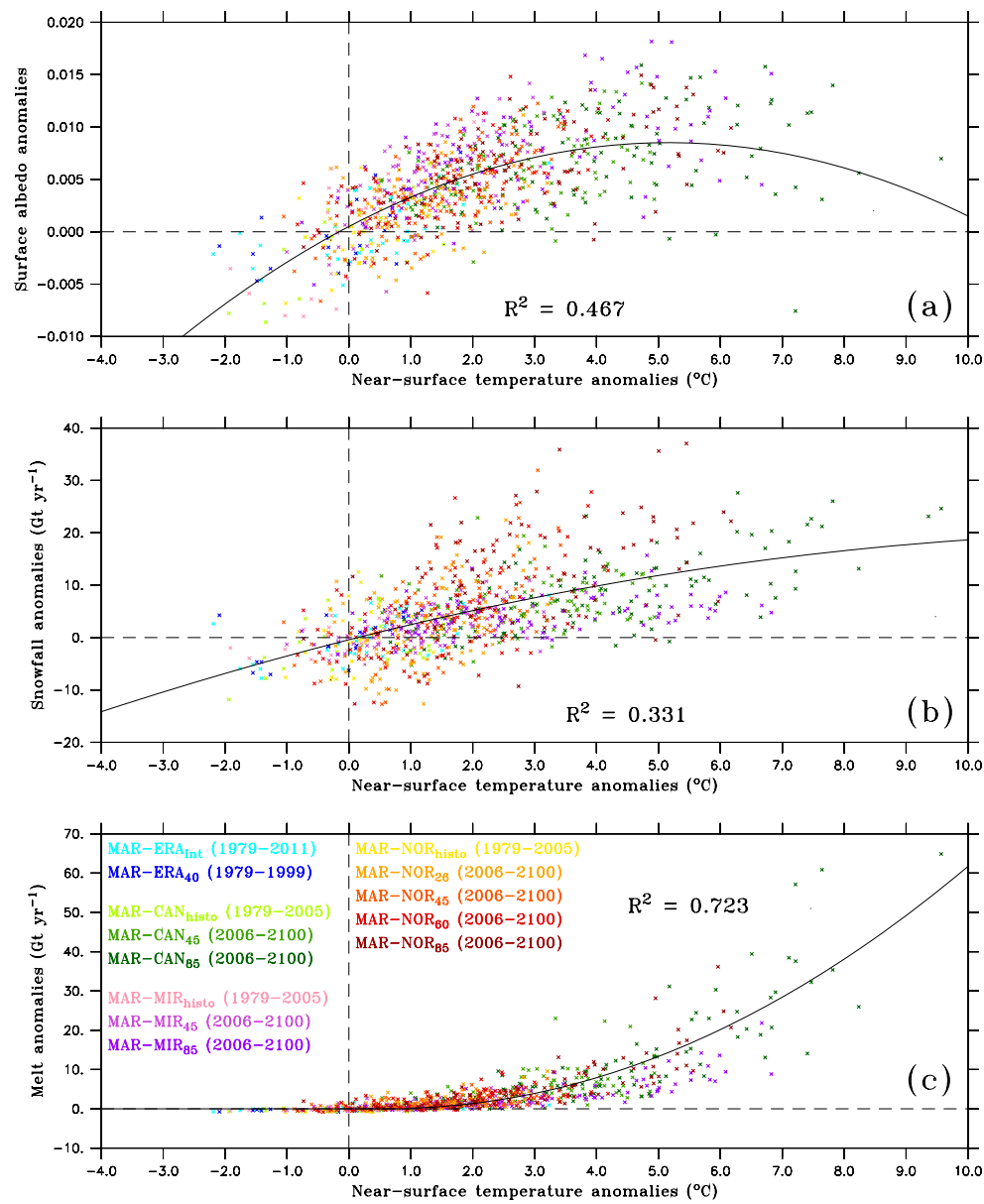

Fig. 7. (a) Summer (from May to September) surface albedo anomalies according to the summer near-surface air temperature anomalies $\left({ }^{\circ} \mathrm{C}\right.$ ) over the central ice sheet $\left(\mathrm{MSK}_{\text {centre}}\right)$ for the MAR simulations forced by the reanalyses and the CMIP5 GCMs, with regression drawn in a solid black line. All the summer anomalies are related to the 1980-1999 average outputs provided by MAR forced with the same forcing

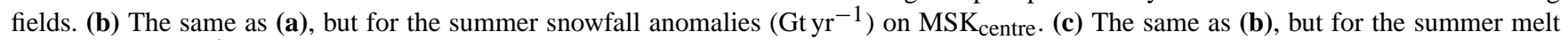
anomalies $\left(\mathrm{Gt} \mathrm{yr}^{-1}\right)$ on $\mathrm{MSK}_{\mathrm{centre}}$.

second most important contribution $(30.25 \%)$ to the 2080 2099 NET increase on the bare ice extent compared to 1980 1999 (Table 4b).

According to Fig. 8, the warm air advection (and hence SHF) appears as the dominant process $(51.46 \%)$ leading the NET response to temperature increase over the bare ice extent, as highlighted for the current climate by van den Broeke et al. $(2008,2011)$.

Finally, the relative contribution of LHF anomalies to the 2080-2099 NET increase is higher on the bare ice extent $(11.67 \%)$ than on the entire melt extent $(5.35 \%)$ of the GrIS, as suggested by Fig. 8 compared to Fig. 5. Because the warmer air over the marginal parts of the ice sheet should contain more moisture (due to an enhanced warm air advection) according to the CMIP5 RCP scenarios, LHF is projected to decrease more rapidly over the bare ice $\left(\mathrm{MSK}_{\text {ice }}\right)$ with increasing temperatures than over the $\mathrm{MSK}_{\text {melt }}$ as a whole.

\section{Conclusion and discussion}

In this study, MAR simulations forced by CMIP5 GCMs (CanESM2, NorESM1-M and MIROC5) with respect to different RCP scenarios have been performed to assess the SEB changes of the GrIS related to Greenland warming. As MAR is only based on physical parameterizations, investigations of the GrIS and its SEB in a warmer climate based on model simulations are easier (but are computationally expensive), as opposed to when statistics are compiled specifically for the current climate. By assessing the anomalies relative to present-day climate, the investigated relationships between the SEB components and air temperature changes have been made independent of the forcing fields or the future scenarios of global warming used for this work.

The MAR future projections have revealed a strong exponential relationship between the GrIS near-surface air temperature and the surface melt. While the melt extent is 

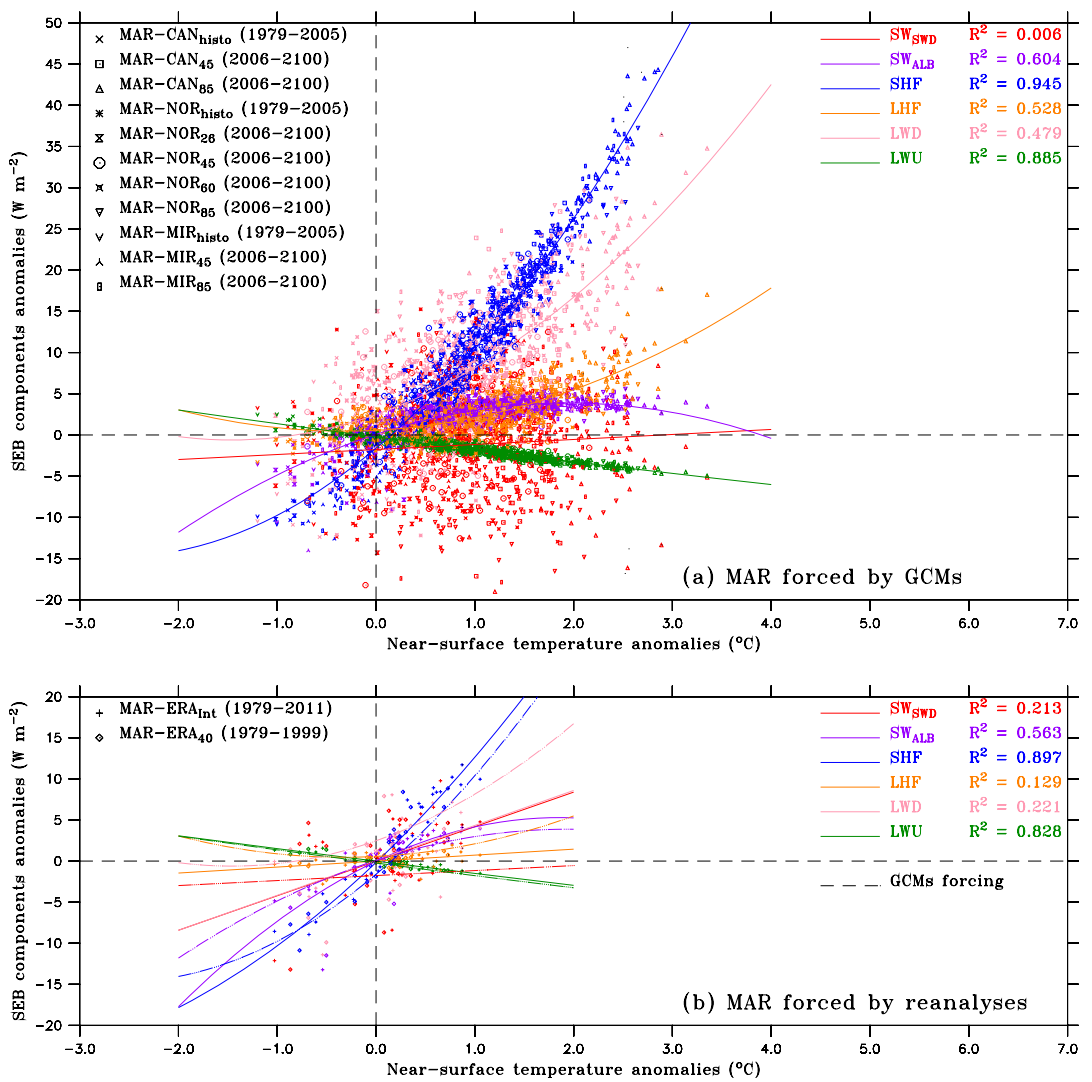

Fig. 8. The same as Fig. 5, but on the 1980-1999 MSK $_{\text {ice }}$.

projected to spread towards the central ice sheet linearly to TAS warming, the increase of bare ice extent (i.e. the ablation zone) is amplified, which affects the albedo, which in turn affects the melt.

The surface albedo is the component most strongly sensitive to an increase in temperature, gradually amplifying the amount of incoming shortwave radiation fluxes absorbed by the ice sheet surface. Nevertheless, along the margins of the ice sheet (especially on the west side), the increase of melt energy is primarily driven by the SHF anomalies due to stronger warm air advection, partly induced by enhanced barrier winds bringing more heat and moisture to the ice sheet. Over central parts of the GrIS, the summer surface albedo is projected to be enhanced by heavier snowfall, but the melt enabled for larger TAS increases eventually surpasses the snowfall feedback by lowering the surface albedo. The limited surface temperature of the melting snow $\left(0^{\circ} \mathrm{C}\right)$ generally impedes the longwave surface emission (LWU) anomalies to counterbalance the increasing LWD due to warmer atmosphere and larger cloud cover, which leads to positive $\mathrm{LW}_{\text {net }}$ changes related to a Greenland warming. The LHF anomalies are not expected to be a significant contributor to the NET increase under a warmer climate over the GrIS.

The ability of CMIP5 GCMs to reproduce the current climate over Greenland with accuracy is very important, be- cause they are required as forcing fields in MAR to perform future projections of the GrIS. Indeed, a GCM that fails to simulate the present-day atmospheric circulation will lack in reliability in future projections. That CanESM2, NorESM1$\mathrm{M}$ and MIROC5 have been proven to be able to reproduce the current climate over Greenland allows the MAR model to provide reliable estimations of the GrIS melt over 19801999 with respect to the ECMWF-forced simulation. Nevertheless, the GCMs are not able to model atmospheric circulation changes observed recently over Greenland that are linked with a decrease of cloudiness in summer. This results in SWD trends (inversely correlated to LWD) over 19801999 that are opposite to those provided by MAR forced with ECMWF reanalyses. Such current biases are a source of uncertainty in future simulations.

Despite the use of different RCP scenarios and different CMIP5 GCMs as forcing fields to perform the future projections of the GrIS, the MAR model has produced outputs (melt, TAS, SEB components) with consistent anomalies relative to the present-day simulations. Such consistency is essential for formulating reliable relationships between the melt, the SEB components and the air temperature anomalies. However, the GCMs used as forcing fields generally constitute the largest part of uncertainty in performing future simulations of the GrIS (Graversen et al., 2011; 
Yoshimori and Abe-Ouchi, 2012). In addition, consistent results related to a specific change of air temperature can only be obtained by forcing the MAR model with GCMs that are able to efficiently model the present-day climate over Greenland. If GCMs are either too cold or too warm for the current climate, the response of the melt will be different for a specific temperature increase, because the melt rate changes are driven by the air temperature anomalies according to a nonlinear (exponential) relationship.

Because the SEB and its changes lead the melt of the GrIS, it is of primary importance to investigate the responses of the runoff of meltwater and the SMB to increasing temperatures over Greenland. This will be the topic of a further study (see Fettweis et al., 2012a).

\section{Supplementary material related to this article is available online at: http://www.the-cryosphere.net/7/1/ 2013/tc-7-1-2013-supplement.pdf.}

Acknowledgements. Bruno Franco is a research fellow of the Belgian National Fund for Scientific Research. The authors acknowledge the climate modelling groups, the Program for Climate Model Diagnosis and Intercomparison (PCMDI), the World Climate Research Programme's (WCRP's) Working Group on Coupled Modelling (WGCM), and the Global Organization for Earth System Science Portals (GO-ESSP) for their roles in producing, coordinating, and making available the CMIP5 model outputs. We also thank the European Centre for Medium Range Weather Forecasts (ECMWF) for the ERA-Interim and ERA-40 reanalyses (http://www.ecmwf.int). Finally, the authors also want to thank Ginna Vogt for her precious spelling check in this manuscript, and two anonymous reviewers for their constructive comments.

Edited by: E. Hanna

\section{References}

Bamber, J. L., Layberry, R. L., and Gogineni, S. P.: A new ice thickness and bed data set for the Greenland ice sheet 1. Measurement, data reduction, and errors, J. Geophys. Res., 106, 33773-33780, doi:10.1029/2001JD900054, 2001.

Belleflamme, A., Fettweis, X., Lang, C., and Erpicum, M.: Current and future atmospheric circulation at $500 \mathrm{hPa}$ over Greenland simulated by the CMIP3 and CMIP5 global models, Clim. Dynam., doi:10.1007/s00382-012-1538-2, 2012.

Box, J. E. and Cohen, A. E.: Upper-air temperatures around Greenland: 1964-2005, Geophys. Res. Lett., 33, L12706, doi:10.1029/2006GL025723, 2006.

Box, J. E., Bromwich, D. H., Veenhuis, B. A., Bai, L.-E., Stroeve, J. C., Rogers, J. C., Steffen, K., Haran, T., and Wang, S.H.: Greenland ice sheet surface mass balance variability (19882004) from calibrated polar MM5 output, J. Climate, 19, 27832800, doi:10.1175/JCLI3738.1, 2006.
Box, J. E., Fettweis, X., Stroeve, J. C., Tedesco, M., Hall, D. K., and Steffen, K.: Greenland ice sheet albedo feedback: thermodynamics and atmospheric drivers, The Cryosphere, 6, 821-839, doi:10.5194/tc-6-821-2012, 2012.

Brun, E., David, P., Sudul, M., and Brunot, G.: A numerical model to simulate snowcover stratigraphy for operational avalanche forecasting, J. Glaciol., 38, 13-22, 1992.

Cazenave, A.: How fast are the ice sheets melting?, Science, 314, 1250-1252, doi:10.1126/science.1133325, 2006.

Comiso, C., Parkinson, C. L., Gerttsen, R., and Stock, L.: Accelerated decline in the Arctic sea ice cover, Geophys. Res. Lett., 35, L01703, doi:10.1029/2007GL031972, 2008.

De Ridder, K. and Gallée, H.: Land surface-induced regional climate change in Southern Israel, J. Appl. Meteorol., 37, 1470-1485, doi:10.1175/15200450(1998)037<1470:LSIRCC>2.0.CO;2, 1998.

Dozier, J., Schneider, S. R., and McGinnis, D. F.: Effect of grainsize and snowpack water equivalence on visible and near-infrared satellite-observations of snow, Water Resour. Res., 17, 12131221, doi:10.1029/WR017i004p01213, 1981.

Ettema, J., van den Broeke, M. R., van Meijgaard, E., van de Berg, W. J., Bamber, J. L., Box, J. E., and Bales, R. C.: Higher surface mass balance of the Greenland ice sheet revealed by highresolution climate modeling, Geophys. Res. Lett., 36, L12501, doi:10.1029/2009GL038110, 2009.

Ettema, J., van den Broeke, M. R., van Meijgaard, E., van de Berg, W. J., Box, J. E., and Steffen, K.: Climate of the Greenland ice sheet using a high-resolution climate model - Part 1: Evaluation, The Cryosphere, 4, 511-527, doi:10.5194/tc-4-511-2010, 2010.

Fettweis, X.: Reconstruction of the 1979-2006 Greenland ice sheet surface mass balance using the regional climate model MAR, The Cryosphere, 1, 21-40, doi:10.5194/tc-1-21-2007, 2007.

Fettweis, X., Gallée, H., Lefebre, L., and van Ypersele, J.- P.: Greenland surface mass balance simulated by a regional climat model and comparison with satellite derived data in 1990-1991, Clim. Dynam., 24, 623-640, doi:10.1007/s00382-005-0010-y, 2005.

Fettweis, X., Tedesco, M., van den Broeke, M., and Ettema, J.: Melting trends over the Greenland ice sheet (1958-2009) from spaceborne microwave data and regional climate models, The Cryosphere, 5, 359-375, doi:10.5194/tc-5-359-2011, 2011a.

Fettweis, X., Belleflamme, A., Erpicum, M., Franco, B., and Nicolay, S.: Estimation of the Sea Level Rise by 2100 Resulting from Changes in the Surface Mass Balance of the Greenland Ice Sheet, in: Climate Change - Geophysical Foundations and Ecological Effects, edited by: Blanco, J. and Kheradmand, H., Intech, Croatia, 503-520, 2011b.

Fettweis, X., Franco, B., Tedesco, M., van Angelen, J. H., Lenaerts, J. T. M., van den Broeke, M. R., and Gallée, H.: Estimating Greenland ice sheet surface mass balance contribution to future sea level rise using the regional atmospheric climate model MAR, The Cryosphere Discuss., 6, 3101-3147, doi:10.5194/tcd6-3101-2012, 2012a.

Fettweis, X., Hanna, E., Lang, C., Belleflamme, A., Erpicum, M., and Gallée, H.: Brief communication "Important role of the midtropospheric atmospheric circulation in the recent surface melt increase over the Greenland ice sheet", The Cryosphere Discuss., 6, 4101-4122, doi:10.5194/tcd-6-4101-2012, 2012 b. 
Franco, B., Fettweis, X., Lang, C., and Erpicum, M.: Impact of spatial resolution on the modelling of the Greenland ice sheet surface mass balance between 1990-2010, using the regional climate model MAR, The Cryosphere, 6, 695-711, doi:10.5194/tc6-695-2012, 2012.

Gallée, H. and Schayes, G.: Development of a three-dimensional meso- $\gamma$ primitive equations model, Mon. Weather Rev., 122, 671-685, 1994

Gallée, H., Guyomarc'h, G., and Brun, E.: Impact of the snow drift on the Antarctic ice sheet surface mass balance: possible sensitivity to snow-surface properties, Bound.-Lay. Meteorol., 99, $1-19,2001$

Graversen, R. G., Drijfhout, S., Hazeleger, W., van de Wal, R., Bintanja, R., and Helsen, M.: Greenland's contribution to global sealevel rise by the end of the 21 st century, Clim. Dynam., 37, 14271442, doi:10.1007/s00382-010-0918-8, 2011.

Gregory, J. M., Huybrechts, P., and Raper, S.: Threatened loss of the Greenland ice sheet, Nature, 428, 616, doi:10.1038/428616a, 2004.

Hall, D. K., Williams, R. S., Luthcke, S. B., and Digirolamo, N. E.: Greenland ice sheet surface temperature, melt and mass loss: 2000-2006, J. Glaciol., 54, 81-93, 2008.

Hanna, E., Huybrechts, P., Janssens, I., Cappelen, J., Steffen, K., and Stephens, A.: Runoff and mass balance of the Greenland ice sheet: 1958-2003, J. Geophys. Res., 110, D13108, doi:10.1029/2004JD005641, 2005.

Hanna, E., Huybrechts, P., Steffen, K., Cappelen, J., Huff, R., Shuman, C., Irvine-Fynn, T., Wise, S., and Griffiths, M.: Increased runoff from melt from the Greenland Ice Sheet: a response to global warming, J. Climate, 21, 331-341, doi:10.1175/2007JCLI1964.1, 2008.

Hanna, E., Cappelen, J., Fettweis, X., Huybrechts, P., Luckman, A., and Ribergaard, M. H.: Hydrologic response of the Greenland ice sheet: the role of oceanographic warming, Hydrol. Process., 23, 7-30, doi:10.1002/hyp.7090, 2009.

Hanna, E., Jones, J. M., Cappelen, J., Mernild, S. H., Wood, L., Steffen, K., and Huybrechts, P.: The influence of North Atlantic atmospheric and oceanic forcing effects on 1900-2010 Greenland summer climate and ice melt/runoff, Int. J. Climatol., doi:10.1002/joc.3475, 2012.

Howat, I. M., Joughin, I., Fahnestock, B. E., Smith, T. A., and Cambos, T. A.: Synchronous retreat and acceleration of southeast Greenland outlet glaciers 2000-2006: ice dynamics and coupling to climate, J. Glaciol., 54, 646-660, 2008.

Knap, W. H. and Oerlemans, J.: The surface albedo of the Greenland ice sheet: satellite-derived and in situ measurements in the Søndre Strømfjord area during the 1991 melt season, J. Glaciol., 42, 364-374, 1996.

Lefebre, F., Gallée, H., van Ypersele, J., and Greuell, W.: Modeling of snow and ice melt at ETH-camp (west Greenland): a study of surface albedo, J. Geophys. Res., 108, 4231, doi:10.1029/2001JD001160, 2003.

Lemke, P., Ren, J., Alley, R. B., Allison, I., Carrasco, J., Flato, G., Fujii, Y., Kaser, G., Mote, P., Thomas, R. H., and Zhang, T.: Observations: Changes in Snow, Ice and Frozen Ground, in: Climate Change 2007: The Physical Science Basis, Contribution of Working Group I to the Fourth Assessment Report of the Intergovernmental Panel on Climate Change, edited by: Solomon, S., Qin, D., Manning, M., Chen, Z., Marquis, M., Averyt, K. B., Tig- nor, M., and Miller, H. L., Cambridge University Press, Cambridge, UK and New York, NY, USA, 2007.

Lindsay, R. W. and Zhang, J.: The thinning of Arctic Sea ice, 19882003: have we passed a tipping point?, J. Climate, 18, 48794894, doi:10.1175/JCLI3587.1, 2005.

Meehl, G. A., Stocker, T. F., Collins, W. D., Friedlingstein, P., Gaye, A. T., Gregory, J. M., Kitoh, A., Knutti, R., Murphy, J. M., Noda, A., Raper, S. C. B., Watterson, I. G., Weaver, A. J., and Zhao, Z. C.: Global climate projections, in: Climate change 2007: The Physical Science Basis, Contribution of Working Group I to the Fourth Assessment Report of the Intergovernmental Panel on Climate Change, edited by: Solomon, S., Qin, D., Manning, M., Chen, Z., Marquis, M., Averyt, K. B., Tignor, M., and Miller, H. L., Cambridge University Press, Cambridge, UK and New York, NY, USA, 2007.

Moss, R., Edmonds, J., Hibbard, K., Manning, M., Rose, S., van Vuuren, D., Carter, T., Emori, S., Kainuma, M., Kram T., Meehl, G., Mitchell, J., Nakicenovic, N., Riahi, K., Smith, S., Stouffer, R., Thomson, A., Weyant, J., and Wilbanks, T.: The next generation of scenarios for climate change research and assessment, Nature, 463, 747-756, doi:10.1038/nature08823, 2010.

Mote, T. L.: Greenland surface melt trends 1973-2007: evidence of a large increase in 2007, Geophys. Res. Lett., 34, L22507, doi:10.1029/2007GL031976, 2007.

Overland, J., Wang, M., Bond, N., Walsh, J., Kattsov, V., and Chapman, W.: Considerations in the selection of Global Climate Models for regional climate projections: the Arctic as a case study, $\mathrm{J}$ Climate, 24, 1583-1597, doi:10.1175/2010JCLI3462.1, 2011.

Overland, J. E., Francis, J. A., Hanna, E., and Wang, M.: The recent shift in early summer Arctic atmospheric circulation, Geophys. Res. Lett., 39, L19804, doi:10.1029/2012GL053268, 2012.

Rae, J. G. L., Aðalgeirsdóttir, G., Edwards, T. L., Fettweis, X., Gregory, J. M., Hewitt, H. T., Lowe, J. A., Lucas-Picher, P., Mottram, R. H., Payne, A. J., Ridley, J. K., Shannon, S. R., van de Berg, W. J., van de Wal, R. S. W., and van den Broeke, M. R.: Greenland ice sheet surface mass balance: evaluating simulations and making projections with regional climate models, The Cryosphere, 6 , 1275-1294, doi:10.5194/tc-6-1275-2012, 2012.

Rignot, E. and Kanagaratnam, P.: Changes in the velocity structure of the Greenland ice sheet, Science, 311, 986-990, doi:10.1126/science.1121381, 2006.

Rignot, E., Box, J. E., Burgess, E., and Hanna, E.: Mass balance of the Greenland ice sheet from 1958 to 2007, Geophys. Res. Lett., 35, L20502, doi:10.1029/2008GL035417, 2008.

Roesch, A., Gilgen, H., Wild, M., and Ohmura, A.: Assessment of GCM simulated snow albedo using direct observations, Clim. Dynam., 15, 405-418, doi:10.1007/s003820050290, 1999.

Serreze, M., Holland, M., and Stroeve, J.: Perspectives on the Arctic's shrinking sea-ice cover, Science, 3158, 1533-1536, doi:10.1126/science.1139426, 2007.

Steffen, K. and Box, J. E.: Surface climatology of the Greenland ice sheet: Greenland climate network 1995-1999, J. Geophys. Res., 106, 33951-33964, doi:10.1029/2001JD900161, 2001.

Stendel, M., Christensen, J. H., and Petersen, D.: Arctic climate and climate change with a focus on Greenland, Adv. Ecol. Res., 40, 13-43, doi:10.1016/S0065-2504(07)00002-5, 2008.

Stroeve, J. C., Serreze, M. C., Fetterer, F., Arbetter, T., Meier, W., Maslanik, J., and Knowles, K.: Tracking the Arctic's shrinking ice cover: Another extreme September minimum in 2004, Geo- 
phys. Res. Lett., 32, L04501, doi:10.1029/2004GL021810, 2005.

Stroeve, J., Holland, M. M., Meier, W., Scambos, T., and Serreze, M.: Arctic sea ice decline: faster than forecast, Geophys. Res. Lett., 34, L09501, doi:10.1029/2007GL029703, 2007.

Sundal, A. V., Shepherd, P., Nienow, P., Hanna, E., Palmer, S., and Huybrechts, P.: Melt-induced speed-up of Greenland ice sheet offset by efficient subglacial drainage, Nature, 469, 521-524, doi:10.1038/nature09740, 2011.

Tedesco, M.: Snowmelt detection over the Greenland ice sheet from SSM/I brightness temperature daily variations, Geophys. Res. Lett., 34, L02504, doi:10.1029/2006GL028466, 2007.

Tedesco, M., Serreze, M., and Fettweis, X.: Diagnosing the extreme surface melt event over southwestern Greenland in 2007, The Cryosphere, 2, 159-166, doi:10.5194/tc-2-159-2008, 2008.

Tedesco, M., Fettweis, X., van den Broeke, M., van de Wal, R., Smeets, P., van de Berg, W. J., Serreze, M., and Box, J.: The role of albedo and accumulation in the 2010 melting record in Greenland, Environ. Res. Lett., 6, 014005, doi:10.1088/17489326/6/1/014005, 2011.

van de Wal, R. S. W., Greuell, W., van den Broeke, M. R., Reijmer, C. H., and Oerlemans, J.: Surface mass-balance observations and automatic weather station data along a transect near Kangerlussuaq, West Greenland, Ann. Glaciol., 42, 311-316, doi:10.3189/172756405781812529, 2005.

van de Wal, R. S. W., Boot, W., van den Broeke, M. R., Smeets, C. J. P. P., Reijmer, C. H., Donker, J. J. A., and Oerlemans, J.: Large and rapid melt-induced velocity changes in the ablation zone of the Greenland ice sheet, Science, 321, 111-113, doi:10.1126/science.1158540, 2008.

van den Broeke, M. R. and Gallée, H.: Observation and simulation of barrier winds at the western margin of the Greenland ice sheet, Q. J. Roy. Meteorol. Soc., 122, 1365-1383, doi:10.1002/qj.49712253407, 1996. van den Broeke, M., Smeets, P., Ettema, J., van der Veen, C., van de Wal, R., and Oerlemans, J.: Partitioning of melt energy and meltwater fluxes in the ablation zone of the west Greenland ice sheet, The Cryosphere, 2, 179-189, doi:10.5194/tc-2-179-2008, 2008.

van den Broeke, M. R., Bamber, J., Ettema, J., Rignot, E., Schrama, E., van de Berg, W. J., van Meijgaard, E., Velicogna, I., and Wouters, B.: Partitioning recent Greenland mass loss, Science, 326, 984-986, doi:10.1126/science.1178176, 2009.

van den Broeke, M. R., Smeets, C. J. P. P., and van de Wal, R. S. W.: The seasonal cycle and interannual variability of surface energy balance and melt in the ablation zone of the west Greenland ice sheet, The Cryosphere, 5, 377-390, doi:10.5194/tc-5-377-2011, 2011.

Walsh, J., Chapman, W., Romanovsky, V., Christensen, J., and Stendel, M.: Global climate model performance over Alaska and Greenland, J. Climate, 21, 6156-6174, doi:10.1175/2008JCLI2163.1, 2008.

Wiscombe, W. J. and Warren, S. G.: A model for the spectral albedo of snow, 1. Pure snow, J. Atmos. Sci., 37, 2712-2733, doi:10.1175/1520-0469(1980)037<2712:amftsa>2.0.co;2, 1980.

Yoshimori, M. and Abe-Ouchi, A.: Sources of spread in multimodel projections of the Greenland ice sheet surface mass balance, J Climate, 25, 1157-1175, doi:10.1175/2011JCLI4011.1, 2012.

Zuo, Z. and Oerlemans, J.: Modelling albedo and specific balance of the Greenland ice sheet: Calculations for the Søndre Strømfjord transect, J. Glaciol., 42, 305-317, 1996.

Zwally, H. J., Abdalati, W., Herring, T., Larson, K., Saba, J., and Steffen, K.: Surface melt-induced acceleration of Greenland icesheet flow, Science, 297, doi:10.1126/science.1072708, 2002. 